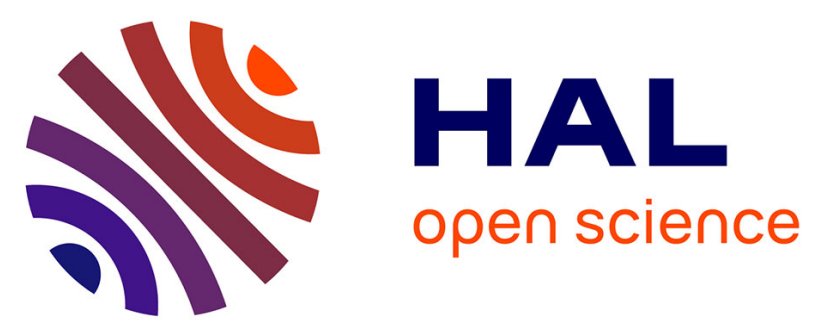

\title{
A dual isotopic (32P and 180) incubation study to disentangle mechanisms controlling phosphorus cycling in soils from a climatic gradient (Kohala, Hawaii)
}

Maja Barbara Siegenthaler, Federica Tamburini, Emmanuel Frossard, Oliver

Chadwick, Peter Vitousek, Chiara Pistocchi, Éva Mészáros, Julian Helfenstein

\section{To cite this version:}

Maja Barbara Siegenthaler, Federica Tamburini, Emmanuel Frossard, Oliver Chadwick, Peter Vitousek, et al.. A dual isotopic (32P and 18O) incubation study to disentangle mechanisms controlling phosphorus cycling in soils from a climatic gradient (Kohala, Hawaii). Soil Biology and Biochemistry, 2020, 149, pp.107920. 10.1016/j.soilbio.2020.107920 . hal-02948550

\section{HAL Id: hal-02948550 \\ https://hal.inrae.fr/hal-02948550}

Submitted on 24 Sep 2020

HAL is a multi-disciplinary open access archive for the deposit and dissemination of scientific research documents, whether they are published or not. The documents may come from teaching and research institutions in France or abroad, or from public or private research centers.
L'archive ouverte pluridisciplinaire HAL, est destinée au dépôt et à la diffusion de documents scientifiques de niveau recherche, publiés ou non, émanant des établissements d'enseignement et de recherche français ou étrangers, des laboratoires publics ou privés. 
This document is the accepted manuscript version of the following article:

Maja Barbara Siegenthaler ${ }^{a, *}$, Federica Tamburini ${ }^{a}$, Emmanuel Frossard $^{a}$, Oliver Chadwick ${ }^{b}$, Peter Vitousek ${ }^{\mathrm{c}}$, Chiara Pistocchia,d, Éva Mészáros ${ }^{\mathrm{a}}$, Julian Helfenstein ${ }^{\mathrm{a}, \mathrm{e}}$ (2020)

A dual isotopic $\left({ }^{32} \mathrm{P}\right.$ and $\left.{ }^{18} \mathrm{O}\right)$ incubation study to disentangle mechanisms controlling phosphorus cycling in soils from a climatic gradient (Kohala, Hawaii)

Soil Biology and Biochemisty. Publisher DOI: https://doi.org/10.1016/j.soilbio.2020.107920

This manuscript version is made available by the CC-BY-NC-ND 4.0 license http://creativecommons.org/licenses/by-nc-nd/4.0/

Originally uploaded to www.tambrix.net/pubs.html on 11 August 2020

\section{Author information:}

a Institute of Agricultural Sciences, ETH Zurich, Eschikon 33, 8315 Lindau, Switzerland

b Department of Geography, University of California, Santa Barbara, 93106 California, USA

c Department of Biology, Stanford University, Stanford, 94305 California, USA

d Eco\&Sols, Montpellier SupAgro, University of Montpellier, CIRAD, INRA, IRD, F-34060 Montpellier, France

e Agroecology and Environment, Agroscope, Reckenholzstrasse 191, 8046 Zurich, Switzerland

\section{Corresponding author information:}

* Maja Barbara Siegenthaler, Institute of Agricultural Sciences, Swiss Federal Institute of Technology Zurich (ETH), Eschikon 33, 8315 Lindau, Switzerland.

E-mail address: maja.siegenthaler@usys.ethz.ch

Keywords: phosphorus cycling, phosphorus radioisotopes, oxygen isotopic signature, andosols, climatic gradient 


\section{Abstract}

Changes in the isotopic composition of oxygen associated with phosphate can provide information on the impact of phosphatase activity on soil $P$ dynamics, whereas the use of radioactive $\mathrm{P}$ delivers information on $\mathrm{P}$ fluxes within soil systems. Although these two tracers may provide complementary data, they have rarely been used together to study soil P cycling. We conducted a dual isotopic soil incubation study of one month with soils originating from four sites of a climatic gradient (Kohala, Hawaii), which provides well-controlled geochemical and biological variations on soils derived from the same parent material. Three groups of soils were incubated in parallel, the first group labelled with ${ }^{32} \mathrm{P}$ radioisotopes, the second group labelled with ${ }^{18} \mathrm{O}$ enriched water and the third group not labelled and used for $\mathrm{CO}_{2}$ emission measurements. The dual labelling study informed about three processes controlling $P$ dynamics in soils: those that maintain the bond between $\mathrm{P}$ and $\mathrm{O}$ and transfer phosphate from one pool to another (category I processes), those that involve the cleavage of the P-O bond and transfer phosphate from one pool to another (category lla processes), and those that involve the cleavage of the P-O bond but do not transfer phosphate from one pool to another (category Ilb processes). The use of ${ }^{32} \mathrm{P}$ showed that the studied soils contained a large amount of $\mathrm{P}$ that was isotopically exchangeable with the resin $\mathrm{P}$ pool (category I process) and that microorganisms had taken up $\mathrm{P}$, but in much lower amounts, from the resin $\mathrm{P}$ pool (category I process). ${ }^{18} \mathrm{O}$ added with water was incorporated into microbial and resin $\mathrm{P}$, but not into the other pools obtained from the modified Hedley extraction. Thus, the turnover of $\mathrm{O}$ associated with $\mathrm{P}$ within microbial cells (category Ilb process) and/or enzymatic hydrolysis of organic $\mathrm{P}$ (category lla process) had occurred and had affected active microbes, which passed the ${ }^{18} \mathrm{O}$ labelled phosphate to the resin pool (category I process). The dual isotopic approach thus provided complementary insights on $\mathrm{P}$ cycling processes. 


\section{Introduction}

Phosphorus (P) transformations in soils are controlled by sorption/desorption, precipitation/dissolution, microbial mineralisation/immobilisation, plant uptake and death, and organic matter dynamics (Frossard et al., 2000; Oberson and Joner, 2005; McLaren et al., 2019). These transformations are most often studied by using sequential chemical extractions, such as the one developed by Hedley et al. (1982). However, information on P distribution among chemical extracts provides a static picture of what is present at a given time; it does not provide information on $\mathrm{P}$ cycling processes (Helfenstein et al., 2018). Abiotic and biotic $\mathrm{P}$ cycling processes are constantly occurring in the soil even if extracted amounts of $\mathrm{P}$ stay constant. Approaches that integrate tracers are therefore required to better understand soil $\mathrm{P}$ fluxes and transformations.

In this paper, we evaluate processes controlling $\mathrm{P}$ dynamics in soils by targeting the isotopic composition of phosphate molecules, in which one $\mathrm{P}$ atom is bound to four oxygen $(\mathrm{O})$ atoms. Diverse process categories are differentiated (Figure 1): those that involve entire phosphate molecules moving as intact units from one pool to another (category I processes), and therefore, the P-O bonds remain untouched; and those that cleave P-O bonds (category II processes). Within the category II processes, we consider those that lead to a phosphate transfer from one pool to another (category lla processes) and those that do not lead to a phosphate transfer from one pool to another (category llb processes). Sorption/desorption, precipitation/dissolution as well as $\mathrm{P}$ uptake by organisms and release upon cell lysis involve the transfer of phosphate molecules without the cleavage of a P-O bond and therefore can be classified as category I processes. Enzymatic processes mediated by phosphomono- and phosphodiesterase can be assigned to the category lla processes as they lead to the cleavage of $\mathrm{P}-\mathrm{O}$ bonds and the release of phosphate from phosphomono- or phosphodiesters to the soil solution (Blake et al., 2005). Finally, the exchange of $O$ atoms on a phosphate mediated by pyrophosphatase within a cell can be assigned to a category Ilb process as the phosphate stays in the same pool (Tamburini et al., 2014). 


\section{Location Figure 1}

Radioactive $\mathrm{P}$ isotopes $\left({ }^{32} \mathrm{P},{ }^{33} \mathrm{P}\right)$ are used to trace the fate of $\mathrm{P}$ in soil-plant systems. More specifically, $\mathrm{P}$ radioisotopes are used to measure phosphate exchange kinetics between the soil solution and the soil solid phase for assessment of the within a given time isotopically exchangeable phosphate, to estimate the rate of organic $\mathrm{P}$ mineralisation, or to quantify the $\mathrm{P}$ uptake by a plant or the $\mathrm{P}$ recovery from an external source (e.g. a plant residue or a fertilizer) in a specific soil pool (Frossard et al., 2011). Some of these P fluxes are controlled by category I processes (sorption/desorption assessed by isotopic exchange, release of phosphate from dead microbes to the soil solution pool), while other $\mathrm{P}$ fluxes belong to category lla (organic $\mathrm{P}$ hydrolysis with P-O bond cleavage and release of phosphate to the soil solution).

In the absence of biological activity and at earth surface temperatures, the P-O bond in phosphate is stable and the isotopic composition of $\mathrm{O}$ associated with $\mathrm{P}\left(\delta^{18} \mathrm{O}-P\right)$ remains constant (Blake et al., 2005; Tamburini et al., 2014). Small changes in $\delta^{18} O-P$ can occur without cleavage of P-O bonds, for instance during apatite dissolution (Liang and Blake, 2007; Jaisi et al., 2010), during short-term sorption (Jaisi et al., 2010; Melby et al., 2013b), or during P uptake by microorganisms (Blake et al., 2005). Enzyme-mediated reactions have on the contrary a strong impact on $\delta^{18} \mathrm{O}-\mathrm{P}$. They lead to $\mathrm{P}-\mathrm{O}$ bond cleavage and $\mathrm{O}$ atom exchange between phosphate and water (category II processes), which either results in the equilibration of $\delta^{18} \mathrm{O}$ $P$ with ${ }^{18} \mathrm{O}$ of water or causes kinetic isotope fractionation effects. Temperature-dependent equilibration can lead to complete $\mathrm{O}$ exchange over time and is considered to be mainly intracellular and mediated by pyrophosphatase (Chang and Blake, 2015; von Sperber et al., 2017b). Intra- and extra-cellular hydrolysis of organic P cleave one (monoester) or two (diester) P-O bonds. Oxygen atoms from water are integrated into the newly formed phosphate (Liang and Blake, 2006b; Liang and Blake, 2009; von Sperber et al., 2014) with an enzyme-dependent kinetic fractionation.

Phosphorus radioisotopes and stable $\mathrm{O}$ isotopes in phosphate have rarely been considered together. An early study conducted by Larsen et al. (1989) showed that when phosphate 
labelled with both ${ }^{18} \mathrm{O}$ and ${ }^{32} \mathrm{P}$ was added to a soil on which ryegrass was grown, the plant recovered much less ${ }^{18} \mathrm{O}$ than ${ }^{32} \mathrm{P}$ compared to what had been added. The authors concluded that the phosphate had lost its ${ }^{18} \mathrm{O}$ before plant uptake. Furthermore, these authors showed that the phosphate extracted by a resin (plant-available $\mathrm{P}$ ) at the end of the pot experiment had a lower ${ }^{18} \mathrm{O} /{ }^{32} \mathrm{P}$ ratio compared to the added source. They suggested that the loss of the ${ }^{18} \mathrm{O}$ label associated with $\mathrm{P}$ was related to soil biological activity. These results were subsequently confirmed by Saaby Johansen et al. (1991) and Melby et al. (2013a) who showed that the loss of ${ }^{18} \mathrm{O}$ from ${ }^{18} \mathrm{O}$ labelled phosphate added to soils was related to biological activity. Scheerer et al. (2019) supplied beech roots with ${ }^{18} \mathrm{O}$ labelled phosphate and with ${ }^{33} \mathrm{P}$ labelled phosphate via addition to the nutrient solution. They could not observe a correlation between root phosphate uptake determined by incorporation of ${ }^{33} \mathrm{P}$ and by incorporation of ${ }^{18} \mathrm{O}$. Thus, the phosphate which had been taken up had lost its ${ }^{18} \mathrm{O}$ signature due to a rapid turnover of $\mathrm{P}$ within roots. Pfahler et al. (2017) supplied soybeans with ${ }^{33} \mathrm{P}$ labelled phosphate and measured the changes in $\delta^{18} \mathrm{O}-\mathrm{P}$ after having stopped or not stopped $\mathrm{P}$ inputs. With the ${ }^{33} \mathrm{P}$ tracing, the authors quantified the transfer of $\mathrm{P}$ from older plant leaves to younger plant organs when $\mathrm{P}$ inputs to the plants were stopped. Also, they showed the occurrence of organic P hydrolysis in older leaves based on the changes in $\delta^{18} O-P$. Further, Helfenstein et al. (2018) assessed the rate of phosphate exchangeability by use of ${ }^{33} \mathrm{P}$ and measured $\delta^{18} \mathrm{O}-\mathrm{P}$ in $\mathrm{P}$ pools extracted sequentially from soils of the Kohala climatic gradient on the island of Hawaii. The use of ${ }^{33} \mathrm{P}$ showed that the soil present at the wettest site had the lowest amount of very slowly exchangeable $\mathrm{P}$, and therefore probably a low concentration of $\mathrm{P}$ present in crystallized forms. The high $\delta^{18} \mathrm{O}-\mathrm{P}$ value observed in the $\mathrm{HCl}$ extractable $\mathrm{P}$ from the sequential extraction measured on this soil showed that the $\mathrm{P}$ recovered in this fraction could not be the original apatite derived from the parent material because the $\mathrm{O}$ associated with $\mathrm{P}$ had been biologically cycled either by plants and/or by microorganisms. The results obtained in the above-mentioned studies show that the use of $\mathrm{P}$ radioisotopes and ${ }^{18} \mathrm{O}$ can provide complementary information related to category I and II processes. However, up to now, no experiment has attempted to simultaneously assess the importance of these processes in controlling soil P dynamics. 
The objective of this study was to assess whether the addition of water labelled with ${ }^{18} \mathrm{O}$ and of radioactive phosphate to soils would allow us to better understand the importance of category I and II processes during a short-term incubation and how this would improve our understanding of $\mathrm{P}$ transformations. This objective was reached by determining $\mathrm{P}$ transfer between different $P$ pools with radioactive $P\left({ }^{32} \mathrm{P}\right)$, by assessing the incorporation of $O$ from ${ }^{18} \mathrm{O}$ enriched water into phosphate present in different soil pools, and by relating these patterns to soil properties. The incubation was conducted for 34 days with four soils originating from the Kohala climatic gradient on the Big Island of Hawaii. These soils were chosen as they provide a strong gradient in edaphic properties while deriving from the same parent material (Chadwick et al., 2003; Vitousek and Chadwick, 2013; Peay et al., 2017; Helfenstein et al., 2018).

\section{Materials and methods}

\subsection{Sampling sites and soil sample collection and preparation}

Soils from four sites on the Kohala climatic gradient located on the leeward slope of the Kohala Peninsula on the Big Island of Hawaii (USA) were studied (Table SM1). Soils are classified as volcanically derived andosols (Chadwick et al., 2003). The soils developed on a Hawi lava flow produced 150,000 years ago (Spengler and Garcia, 1988). The lava is an alkali basalt and contains large amounts of apatite (Chadwick et al., 2003). Mean annual rainfall of the sites 1 to 4 covers a wide range $\left(275,1578,2163\right.$, and $\left.3123 \mathrm{~mm} \mathrm{y}^{-1}\right)$, whereas mean annual temperature varies in comparison on a smaller range (16.2, 17.8, 19.1, and $23.6{ }^{\circ} \mathrm{C}$ ) (Giambelluca et al., 2013). The main vegetation is grassland dominated by either buffel grass (Pennisetum ciliare L.) or kikuyu grass (Pennisetum clandestinum Hochst. ex Chiov.) (von Sperber et al., 2017a).

Soil samples were taken in February 2016 and in February 2017 from the A horizon of the four sites. The soil samples were kept at room temperature during shipment to Switzerland (one week) and were then stored immediately at $-20^{\circ} \mathrm{C}$ until processing (13 months for February 2016 samples and one month for February 2017 samples, respectively). Soil samples of both 
sampling times were unfrozen, sieved moist at $2 \mathrm{~mm}$, and combined to form one composite sample per site in March 2017. Afterwards, soils were kept again at $-20{ }^{\circ} \mathrm{C}$ until usage (up to two weeks). The combination of the soil samples from the two sampling times was performed to meet the soil dry weight needs of the experiment, this was required due to imposed restrictions on soil sampling and shipment. It was assumed that the soil sampling time and therefore the sample combination does not affect the strong gradient in soil properties, which was the underlying reason for the choice of the sites. However, an impact on microorganisms and available nutrient pools was expected but considered negligible in comparison to changes due to the applied conditions during the incubation experiment.

The water content of field moist soil was determined by drying for 20 hours at $105{ }^{\circ} \mathrm{C}$. The water holding capacity (WHC) of field moist soils was determined by first weighing the soils into tared cylinders to a defined height, then saturating the soils with water by putting them in a water bath for 3 hours, and lastly allowing gravitational water to drain by placing the cylinders on a sand bath for 3.75 hours. For the pre-incubation, the water content of the soils was adjusted to $60 \%$ max. WHC by drying the soils at $28{ }^{\circ} \mathrm{C}$ (soils of sites 3 and 4 ) and water addition (soils of all four sites).

\subsection{Experimental design}

Separate soil subsamples were used for the two tracer $\left({ }^{32} \mathrm{P}\right.$ and $\left.{ }^{18} \mathrm{O}\right)$ and the respiration experiments. The incubation of labelled soils lasted 34 days, the respiration measurements lasted 36 days. All soils were incubated in the dark at $25^{\circ} \mathrm{C}$ and $70 \%$ air humidity. After 23 days of pre-incubation at initially $60 \%$ WHC, soils were watered to adjust for evaporation losses and mixed before being assigned to either the labelling or the respiration experiments. Equivalents of $15 \mathrm{~g}$ of dry soil were weighed into jars to measure soil respiration, while equivalents of $30 \mathrm{~g}$ of dry soil were weighed into $250 \mathrm{ml}$ plastic bottles for the tracer ( ${ }^{32} \mathrm{P}$ and ${ }^{18} \mathrm{O}$ ) experiments (Table 1 ). After adding water and labelling solution, all soils were again at $60 \% \mathrm{WHC}$

\section{Location Table 1}


For the ${ }^{32} \mathrm{P}$ experiment, each sample was labelled with carrier-free ${ }^{32} \mathrm{P}$ added in the form of phosphoric acid (Hartmann Analytic $\mathrm{GmbH}$, Braunschweig, Germany) at a rate of $0.034 \mathrm{MBq}$ $\mathrm{g}^{-1}$ for samples of sites 1 and 2 , and $0.045 \mathrm{MBq} \mathrm{g}^{-1}$ for samples of sites 3 and 4 , respectively. The rates of ${ }^{32} \mathrm{P}$ applied were based on pre-tests conducted on test samples in $2015 .{ }^{32} \mathrm{P}$ was selected due to a delivery shortage of ${ }^{33} \mathrm{P}$. The same experiment could have been carried out with ${ }^{33} \mathrm{P}$, as there is no significant isotopic fractionation between ${ }^{31} \mathrm{P},{ }^{32} \mathrm{P}$, and ${ }^{33} \mathrm{P}$ (Frossard et al., 2011). Four replicates were prepared for each time point and site combination by mixing the soil with the radioactive solution for two minutes in the plastic bottle. During the incubation, the samples were arranged according to a random complete block design with one replicate of each time point and site combination per block. Soils were sampled destructively at five time points $(1,4,14,26$ and 34 days after labelling). Resin and microbial $\mathrm{P}$ contents and radioactive counts were measured at each time point to capture the dynamic isotopic exchange. Further explanatory analyses (total and chloroform-labile $\mathrm{C}$ and $\mathrm{N}$, potential acid phosphatase activity, water-extractable $\mathrm{P}\left(P_{w}\right)$ ) were conducted on these samples at selected time points (Table 1 ). This selection occurred as total and chloroform-labile $\mathrm{C}$ and $\mathrm{N}$ and potential acid phosphatase activity were expected to stay constant over the incubation time and as $P_{\text {resin }}$ was considered a more reliable indicator for available $P$ than $P_{w}$ throughout the incubation.

For the ${ }^{18} \mathrm{O}$ experiment, half of the soil samples were destructively sampled at the incubation start (day 0 ) without adding an ${ }^{18} \mathrm{O}$ label. The other half of the soil samples were labelled with $2 \mathrm{ml}$ of ${ }^{18} \mathrm{O}$ enriched water $\left(\delta^{18} \mathrm{O}\right.$ in labelling water $=300 \%$, prepared by dilution of $98 \%{ }^{18} \mathrm{O}$ enriched water from Sercon Limited, Crewe, UK) by mixing the soil with the enriched water for two minutes in the plastic bottle. This second set of soil samples was then incubated for 34 days before destructive sampling. During the incubation, the ${ }^{18} \mathrm{O}$ labelled soil samples were kept next to the ${ }^{32} \mathrm{P}$ labelled soil samples, but in a separate randomized block. Determination of $\delta^{18} \mathrm{O}$ in soil water $\left(\delta^{18} \mathrm{O}-w_{s}\right)$ and in phosphate $\left(\delta^{18} \mathrm{O}-\mathrm{P}\right)$ of sequentially extracted $\mathrm{P}$ pools (resin $\mathrm{P}$, microbial $\mathrm{P}$, inorganic and organic $\mathrm{NaOH}-\mathrm{EDTA} \mathrm{P}$, and $\mathrm{HCI} \mathrm{P}$ ) was conducted at both time points (day 0 and day 34). Per time point and site combination, four replicates were prepared in plastic bottles. For the analysis of $\delta^{18} \mathrm{O}-\mathrm{P}$ two of the four bottles were pooled into 
one combined sample to reach $\mathrm{P}$ amounts suitable for $\mathrm{Ag}_{3} \mathrm{PO}_{4}$ purification and analysis, resulting in two experimental replicates per site and time point combination. By using the same (volume and brand) plastic bottles and the same amounts of soil in each bottle for ${ }^{32} \mathrm{P}$ and ${ }^{18} \mathrm{O}$ soil samples, equal conditions were provided, and the results of the ${ }^{32} \mathrm{P}$ and ${ }^{18} \mathrm{O}$ experiments are comparable.

\subsection{Analytical methods}

\subsubsection{Total and microbial carbon and nitrogen}

Total soil $\mathrm{C}$ and $\mathrm{N}$ contents were measured on finely ground samples dried at $40{ }^{\circ} \mathrm{C}$ on an elemental analyser (vario PYRO, Elementar Analysesysteme $\mathrm{GmbH}$, Langenselbold, Germany; temperature of combustion $950{ }^{\circ} \mathrm{C}$ ). Microbial $\mathrm{C}$ and $\mathrm{N}$ were estimated by the chloroform fumigation-extraction method of Vance et al. (1987). Fresh samples with a dry weight equivalent of $6 \mathrm{~g}$ dry soil were fumigated for $24 \mathrm{~h}$. Fumigated and non-fumigated subsamples were extracted with $0.5 \mathrm{M} \mathrm{K}_{2} \mathrm{SO}_{4}$ in a 1:4 soil:solution (mass:mass) ratio. The extracts were frozen and then analysed with a TOC/TN analyser for liquid samples (TOC-L, Shimadzu, Kyoto, Japan). The difference between fumigated and non-fumigated subsamples was calculated to estimate microbial $\mathrm{C}$ and $\mathrm{N}$. No conversion factors ( $\mathrm{k}_{\mathrm{C}}$ and $\mathrm{kN}_{\mathrm{N}}$ ) were applied to correct for inefficient fumigation by chloroform, therefore the terms chloroform -labile $\mathrm{C}\left(\mathrm{C}_{\mathrm{ch}}\right)$ and $\mathrm{N}\left(N_{c h l}\right)$ are used instead of microbial $\mathrm{C}$ and $\mathrm{N}$.

\subsubsection{Soil respiration}

Soil respiration was quantified by trapping the released $\mathrm{CO}_{2}$ in $0.2 \mathrm{M} \mathrm{NaOH}$ and back-titrating with $0.2 \mathrm{M} \mathrm{HCl}$ (Alef, 1995). Measurements were performed at 8, 13, 20, 28 and 36 days after the day of labelling (Table 1).

\subsubsection{Phosphatase activity}

Potential acid phosphatase activity in soils was determined by using a 4-methylumbelliferon (MUF) substrate in a microplate assay with 6 analytical replicates following the method developed by Marx et al. (2001) and modified by Poll et al. (2006). The assay was conducted 
for acidic $(\mathrm{pH}$ 6.1) phosphatase activity. Fluorescence was measured on a fluorescence plate reader (Biotek FLx800, Fisher Scientific GmbH, Schwerte, Germany). This analysis was performed on a formerly frozen equivalent of $1 \mathrm{~g}$ dry soil sampled in the ${ }^{32} \mathrm{P}$ incubation experiment at 14 days (Table 1 ).

\subsubsection{Soil phosphorus pool concentrations}

Soil P pool concentrations were assessed on moist soil samples using a modified Hedley sequential extraction (Moir and Tiessen, 2007). The following steps were performed. First three subsamples were treated in parallel: one subsample was extracted with an anion exchange resin $\left(P_{\text {resin }}\right)$, the other was fumigated with liquid hexanol and extracted with an anion exchange resin $\left(P_{\text {hex }}\right)$, and the last was spiked with ${ }^{31} \mathrm{P}$ and extracted with an anion exchange resin $\left(P_{\text {spike }}\right)$. Resins were eluted in $0.1 \mathrm{M} \mathrm{NaCl} / 0.1 \mathrm{M} \mathrm{HCl}$ by shaking horizontally for 2 hours at 150 rpm. The resin extraction provides an estimation of plant-available $P$, the difference in $P$ concentration between the resin extract following fumigation and without fumigation provides an estimate of microbial $\mathrm{P}$, while the last sample allows quantifying the sorption of $\mathrm{P}$ derived from cell lysis following fumigation (Kouno et al., 1995; Bünemann et al., 2004). The subsample that had been fumigated with hexanol and extracted with a resin was subsequently extracted with $0.25 \mathrm{M} \mathrm{NaOH} / 0.05 \mathrm{M}$ EDTA and the extraction residue was then extracted with $1 \mathrm{M} \mathrm{HCl}$. $\mathrm{NaOH} / \mathrm{EDTA}$ is considered to extract inorganic $\mathrm{P}$ bound to $\mathrm{Fe}$ and $\mathrm{Al}$ oxides and organic $\mathrm{P}$, while the $\mathrm{HCl}$ is considered to extract insoluble calcium phosphates, such as apatite (Hedley et al., 1982). Each extraction step was conducted by shaking the respective soil solution horizontally for 16 hours at $150 \mathrm{rpm}$. This sequential extraction was performed before the start of the incubation on each soil with three replicates using a 1:15 soil:solution ratio (Pistocchi et al., 2018).

The protocol of Tamburini et al. (2018) was used to analyse the $\delta^{18} \mathrm{O}-\mathrm{P}$ in the above-mentioned P pools. This protocol uses a 1:10 soil:solution ratio to collect sufficient $P$ for the measurement of the $\delta^{18} \mathrm{O}-P$. These analyses were performed before labelling and 34 days after labelling with ${ }^{18} \mathrm{O}$ enriched water in the ${ }^{18} \mathrm{O}$ experiment. 
Additional extractions for $P_{\text {resin, }} P_{\text {hex }}$ and $P_{\text {spike }}$ and ${ }^{32} \mathrm{P}$ within these pools were performed at 1 , 4, 14, 26 and 34 days after labelling with ${ }^{32} \mathrm{P}$ on the equivalent of $2 \mathrm{~g}$ dry soil with a 1:15 soil:solution ratio on four replicates per site in the ${ }^{32} \mathrm{P}$ experiment following the protocol of Pistocchi et al. (2018). Added $\mathrm{P}$ spikes ranged from 5 to $50 \mathrm{mg} \mathrm{P} \mathrm{kg}^{-1}$ during the ${ }^{32} \mathrm{P}$ experiment depending on soil and sampling time. Water extractable $\mathrm{P}\left(P_{w}\right)$ was determined on moist equivalents of $10 \mathrm{~g}$ dry soil from the incubation 14 days after labelling with ${ }^{32} \mathrm{P}$ for four replicates per soil. The extraction was performed by adding $100 \mathrm{ml} \mathrm{H}_{2} \mathrm{O}$ (accounting for water contained in the soil), shaking overhead for 16 hours at $15 \mathrm{rpm}$, stirring for $30 \mathrm{~min}$ at $200 \mathrm{rpm}$ and then filtering the soil solution $(0.2 \mu \mathrm{m}$ cellulose acetate membrane filter, Whatman, Merck, Darmstadt, Germany). Total P was assessed on four replicates per site on soils that had been incubated for 34 days and then air-dried and finely milled. The extraction was conducted by adding $4 \mathrm{ml}$ of $15.6 \mathrm{M} \mathrm{HNO}_{3}$ to $0.2 \mathrm{~g}$ dry soil at $250{ }^{\circ} \mathrm{C}$ for $20 \mathrm{~min}$ in a microwave (Turbowave, MLS GmbH, Heerbrugg, Switzerland).

The concentrations of resin extractable $\mathrm{P}\left(P_{\text {resin }}\right)$, inorganic $\mathrm{NaOH}-\mathrm{EDTA} \mathrm{P}, \mathrm{HCl} \mathrm{P}$, total soil $\mathrm{P}$, and water $\left(P_{w}\right)$ were determined colourimetrically (UV-1800, Shimadzu, Canby, USA) with the malachite green method of Ohno and Zibilske (1991). Total P in NaOH-EDTA extracts was measured by ICP-OES (ICPE-9820, Shimadzu, Kyoto, Japan). Organic NaOH-EDTA P was calculated as the difference between total and inorganic $\mathrm{P}$ measured in the $\mathrm{NaOH}$-EDTA extract. Microbial P ( $P_{\text {mic }}, \mathrm{mg} \mathrm{P} \mathrm{kg}^{-1}$ dry soil) was calculated as the difference between $P_{\text {hex }}$ and $P_{\text {resin }}$ subsamples including the correction for sorption (Bünemann et al., 2016):

$P_{\text {mic }}=\left(P_{\text {hex }}-P_{\text {resin }}\right) /$ rec

where $P_{\text {hex }}\left(\mathrm{mg} \mathrm{P} \mathrm{kg}^{-1}\right.$ dry soil) is the resin extractable inorganic $\mathrm{P}$ in the fumigated subsample and $P_{\text {resin }}\left(\mathrm{mg} \mathrm{P} \mathrm{kg}^{-1}\right)$ is the resin extractable inorganic $\mathrm{P}$ in the non-fumigated subsample, and rec is the recovery of added $\mathrm{P}$ spike calculated as:

rec $=\left(P_{\text {spike }}-P_{\text {resin }}\right) /$ added $P$

with $P_{\text {spike }}\left(\mathrm{mg} \mathrm{P} \mathrm{kg}^{-1}\right.$ dry soil) being the resin extractable inorganic $\mathrm{P}$ in the subsample to which the $P$ spike had been added. If recovery of added $P$ was above 1 , which happened five times 
during the ${ }^{32} \mathrm{P}$ experiment (four times for site 1 , once for site 2), rec was set to 1 . For the sequential $\mathrm{P}$ extraction before the start of the incubation rec was set to 1 for all sites due to amounts of spike $\mathrm{P}$ added being not close to actual $P_{\text {mic }}$ values resulting in unrealistically low or high rec values. No conversion factor $\left(\mathrm{K}_{\mathrm{P}}\right)$ was applied to correct microbial $\mathrm{P}$ for inefficient fumigation by hexanol, as $\mathrm{k}_{\mathrm{p}}$ is soil-specific (Oberson and Joner, 2005) and was not determined for the studied soils. Thus, microbial P might be underestimated. Microbial P was found three times to be negative (each time in soils from site 1), in such cases $P_{\text {mic }}$ was set to zero.

\subsubsection{Radioisotope tracing in soil phosphorus pools}

\subsubsection{Radioactivity in phosphorus pools}

Radioactivity in the resin extractable pool $\left(r_{\text {resin }}\right)$ was directly measured by scintillation counting on a beta-emission counter (Tri-carb 2500 TR, Packard Instruments, Meriden, USA) using 1 $\mathrm{ml}$ of sample and $5 \mathrm{ml}$ Ultima Gold ${ }^{\mathrm{TM}}$ (Perkin Elmer, USA).

The determination of radioactivity in microbial biomass $\left(r_{\text {mic }}\right)$ was done after having corrected the release of ${ }^{32} \mathrm{P}$ from the solid phase of the soil caused by the release of ${ }^{31} \mathrm{P}$ from the microbial P pool (Bünemann et al., 2016; Schneider et al., 2017). First, a linear correlation was built between $P_{h e x}$ and $r_{\text {spike }}$ (the amount of radioactivity recovered in the sample spiked with ${ }^{31} \mathrm{P}$ in $\mathrm{Bq} \mathrm{g}^{-1}$ dry soil) which is the corrected radioactivity in spiked subsamples

$r_{\text {spike }}=a^{*} P_{h e x}+b$

where $a$ and $b$ are the slope and intercept of the linear regression.

And then $r_{\text {spike }}$ was introduced in equation 4 to obtain $r_{\text {mic }}\left(\mathrm{Bq} \mathrm{g}^{-1}\right.$ dry soil)

$r_{\text {mic }}=\left(r_{\text {hex }}-r_{\text {spike }}\right) /$ rec

This approach assumes that the recovery of $\mathrm{a}^{31} \mathrm{P}$ spike $(r e c)$ is similar to the recovery of $\mathrm{a}^{32} \mathrm{P}$ spike as shown by Bünemann et al. (2012), and therefore that it is not necessary to measure this last parameter. 
Negative values were observed 18 times for $r_{\text {mic }}, 12$ of these negative values were recorded for the soils of site 1 . These values were probably caused by low microbial P concentrations (Table 2) and lower soil microbial activity (Figure 2) combined with propagated measurement uncertainties. Thus, negative values were considered as missing values. As a large fraction of the $r_{\text {mic }}$ values of site 1 were missing, we do not discuss $r_{\text {mic }}$ in the soils of site 1 and focus on the more reliable complementary data.

\subsubsection{Radioactivity recovery and specific activity of phosphorus pools}

Radioactivity recovery $\left(r / R_{p o o l}, \%\right)$ was calculated for each analysed pool by relating the measured radioactivity $r$ in the pool at a given sampling time ( $r_{p o o l} \mathrm{~Bq} \mathrm{~g}^{-1}$ dry soil) to the decayadjusted introduced radioactivity $R\left(\mathrm{~Bq} \mathrm{~g}^{-1}\right.$ dry soil, half-life $\mathrm{t}_{1 / 2}=14.28$ days for $\left.{ }^{32} \mathrm{P}\right)$ :

$r / R_{\text {pool }}=\left(r_{\text {pool }} / R\right) * 100$

Instead of the commonly used specific activity $\left(S A, \mathrm{~Bq} \mathrm{mg}^{-1} \mathrm{P}\right)$, the proportional specific activity in $\mathrm{P}$ pools $\left(p S A_{\text {pool }} \% \mathrm{~kg}\right.$ dry soil $\mathrm{mg}^{-1} \mathrm{P}$ ) was calculated as follows:

$p S A_{\text {pool }}=\left(r / R_{\text {pool }} / P_{\text {pool }}\right)$

where $r / R_{p o o l}$ is the fraction of recovered radioactivity in the $\mathrm{P}$ pool (\%) and $P_{\text {pool }}$ is the $\mathrm{P}$ concentration of the $\mathrm{P}$ pool ( $\mathrm{mg} \mathrm{P} \mathrm{kg}^{-1}$ dry soil). This modification of the calculation was performed to account for the variable amount of introduced ${ }^{32} \mathrm{P}(R)$ and thus to enable the comparison between sites.

\subsubsection{Isotopically exchangeable phosphate}

Isotopically exchangeable phosphate was calculated to assess the fluxes of $P$ between the solid phase of the soil and the solution. Since the measurements of $P_{w}$ were very variable and below the detection limit in the soils of the wetter site 4, we decided to use the resin P pool for the calculation of the isotopically exchangeable phosphate as proposed by Maertens et al.

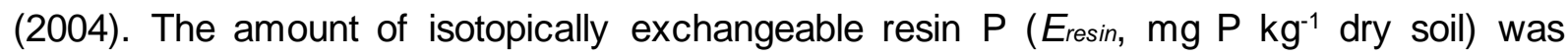
calculated according to the following equation:

$E_{\text {resin }}=100 / p S A_{\text {resin }}$ 
where $p S A_{r e s i n}$ is the proportional specific activity in the resin extract.

\subsubsection{Estimation of gross phosphorus immobilisation}

If we consider that microorganisms take up most of their $\mathrm{P}$ from the resin $\mathrm{P}$ pool then it becomes possible, using $p S A_{\text {resin }}$ and $r / R_{\text {mic }}$, to calculate the amount of microbial $\mathrm{P}$ that is derived from the resin $\mathrm{P}$ pool ( $P_{\text {immo }}, \mathrm{mg} \mathrm{P} \mathrm{kg}^{-1}$ dry soil) using the following equation:

$P_{\text {immo }}=\left(r / R_{\text {mic }}\right) / p S A_{\text {resin }}$

Equation 8 provides an estimation of the gross $P$ immobilisation (Bünemann et al., 2012). The soils from site 1 were not considered for this calculation.

\subsubsection{Oxygen isotopic signatures}

\subsubsection{Oxygen isotopic signatures in soil water and phosphate}

Soil water was extracted by cryogenic vacuum extraction (Orlowski et al., 2013) from one replicate per soil of each site before and 34 days after labelling with ${ }^{18} \mathrm{O}$ enriched water.

Phosphate in the resin, hexanol and $\mathrm{HCl}$ extracts was purified following the protocol given by Tamburini et al. (2010). For $\mathrm{NaOH}-\mathrm{EDTA}$ extracts, separation into organic and inorganic $\mathrm{P}$ fractions and their respective purification were performed following Tamburini et al. (2018). Inorganic $\mathrm{NaOH}$-EDTA extracts were processed for sites 1, 2 and 4, while organic ones were processed only for sites 2 and 4 . These samples were selected because we expected differences to occur between the extreme sites 1 and 4 . As site 1 had not enough $P$ in the organic $\mathrm{NaOH}$-EDTA extract, site 2 was also considered. The $\delta^{18} \mathrm{O}-\mathrm{P}$ of inorganic $\mathrm{NaOH}$-EDTA $\mathrm{P}$ of site 4 was considerably lower at 34 days compared to before labelling with ${ }^{18} \mathrm{O}$ enriched water, suggesting a processing error. Because the analysis could not be repeated due to limited soil availability, the results for site 4 are not shown.

Purified $\mathrm{Ag}_{3} \mathrm{PO}_{4}$ was analysed in one to three analytical replicates for $\delta^{18} \mathrm{O}$ on a thermal conversion elemental analyser (vario PYRO cube, Elementar Analysensysteme GmbH, Langenselbold, Germany) in pyrolysis mode (temperature set at $1450{ }^{\circ} \mathrm{C}$ ), coupled in a 
continuous flow to an IsoPrime 100 isotopic ratio mass spectrometer (IRMS). An internal $\mathrm{Ag}_{3} \mathrm{PO}_{4}$ standard (Acros Organics, Geel, Belgium, $\delta^{18} \mathrm{O}=14.2 \%$ ), two benzoic acid standards distributed by the International Atomic Energy Agency (IAEA) (IAEA 601: $\delta^{18} \mathrm{O}=23.1 \%$, IAEA $602 \delta^{18} \mathrm{O}=71.3 \%$ ) and in-house made standards were used for instrumental drift correction and calibration. Oxygen isotopic signatures are presented in the $\delta^{18} \mathrm{O}$ notation as \%o deviation values related to the VSMOW (Vienna Standard Mean Oceanic Water).

\subsubsection{Calculation of equilibrium oxygen isotopic signature}

The expected $\delta^{18} \mathrm{O}$ signature of phosphate in equilibrium with soil water $\left(E q-W_{s}\right)$ can be calculated with the following equation (Chang and Blake, 2015):

$E q-W_{s}=\mathrm{e}^{\wedge}(14.43 / T-26.54 / 1000){ }^{*}\left(\delta^{18} O-W_{s}+1000\right)-1000$

where $T$ is the temperature in $\mathrm{K}$ during the incubation and $\delta^{18} \mathrm{O}-\mathrm{ws}_{\mathrm{s}}(\%)$ is the $\mathrm{O}$ isotopic signature of soil extracted water.

Since temperature-dependent equilibration is mainly occurring intracellularly, the proportion of water, produced during metabolic reactions, and its $\delta^{18} \mathrm{O}$ should be considered for the equilibrium estimation. The contribution of metabolic water to intracellular water depends on the metabolic state of the organism. It reached up to $70 \%$ for Escherichia coli during active growth, whereas the contribution in a stationary phase was considerably smaller (KreuzerMartin et al., 2005).

Our estimation of the equilibrium considering soil water and metabolic water $\left(E q-w_{s+m}\right)$ was based on two assumptions. First, that intracellular water $\left(\delta^{18} \mathrm{O}-w_{s+m}\right)$ consists of $59 \%$ soil water and $41 \%$ metabolic water, as determined by $\mathrm{Li}$ et al. (2016) due to the fractionation between $\delta^{18} \mathrm{O}$ of microbial biomass and extracellular water. Second, that $\delta^{18} \mathrm{O}$ of metabolic water is 3.5\%o (Kreuzer-Martin et al., 2005). This results in the following equation:

$\delta^{18} O-w_{s+m}=0.59 * \delta^{18} O-w_{s}+0.41 *(-3.5)$ 
where $\delta^{18} \mathrm{O}-w_{s}(\%)$ is the measured $\mathrm{O}$ isotopic signature of soil water, which is accounting for $59 \%$ of water within biomass, and $-3.5 \%$ is the $\delta^{18} \mathrm{O}$ of metabolic water accounting for $41 \%$ of water within biomass (Kreuzer-Martin et al., 2005; Li et al., 2016).

\subsubsection{Calculation of oxygen isotopic signature in phosphate $\left(\delta^{18} \mathrm{O}-\mathrm{P}\right)$}

Most $\delta^{18} \mathrm{O}-P$ values per individual sample were calculated from three analytical replicates of purified $\mathrm{Ag}_{3} \mathrm{PO}_{4}$ measured from this sample. For the organic $\mathrm{NaOH}$-EDTA P extracts, the incorporation of ${ }^{18} \mathrm{O}$ during UV-digestion was negligible and therefore the subsamples (nonlabelled and spiked with ${ }^{18} \mathrm{O}$ enriched water during UV hydrolysis, see Tamburini et al. (2018)) were considered as individual samples for the calculations of mean and corrected sample standard deviation per pool.

The $\delta^{18} \mathrm{O}-P_{\text {mic }}$, the $\mathrm{O}$ isotopic composition of phosphate in the microbial $\mathrm{P}$ pool, was calculated with a mass balance equation (Tamburini et al., 2012):

$\delta^{18} O-P_{\text {mic }}=\left(\delta^{18} O-P_{\text {hex }}{ }^{*} P_{\text {hex }}-\delta^{18} O-P_{\text {resin }}{ }^{*} P_{\text {resin }}\right) /\left(P_{\text {hex }}-P_{\text {resin }}\right)$

where $\delta^{18} \mathrm{O}-P_{\text {hex }}(\%)$ and $\delta^{18} \mathrm{O}-P_{\text {resin }}(\%)$ are the $\mathrm{O}$ isotopic compositions of phosphate in the hexanol and resin $\mathrm{P}$ pools, respectively and $P_{\text {hex }}\left(\mathrm{mg} \mathrm{P} \mathrm{kg}^{-1}\right.$ dry soil) and $P_{\text {resin }}\left(\mathrm{mg} \mathrm{P} \mathrm{kg}^{-1} \mathrm{dry}\right.$ soil) are the $\mathrm{P}$ concentrations in the hexanol and resin $\mathrm{P}$ pools of the respective sample. For sites 1 and $2, \delta^{18} \mathrm{O}-\mathrm{P}$ of the hexanol and resin $\mathrm{P}$ pool were too close to each other to allow a reliable mass balance. Thus, $\delta^{18} \mathrm{O}-P_{h e x}$ was reported instead.

During the $\mathrm{HCl}$ extraction, we used ${ }^{18} \mathrm{O}$ labelled and unlabelled reagents to track possible inorganic hydrolysis related for instance to the presence of pyro- or polyphosphates (Tamburini et al., 2010). If hydrolysis was observed, then the actual $\delta^{18} \mathrm{O}-\mathrm{P}_{\mathrm{HC}} /$ was calculated according to Pistocchi et al. (2017):

$\delta^{18} O-P_{H C l}=\left(\delta^{18} O-P_{l}{ }^{*} \delta^{18} O-W_{n l}-\delta^{18} O-P_{n l}{ }^{*} \delta^{18} O-W l\right) /\left(\delta^{18} O-P_{l}-\delta^{18} O-P_{n l}-\delta^{18} O-W l+\delta^{18} O-W_{n l}\right)$ 
where $\delta^{18} \mathrm{O}-P_{l}(\%)$ and $\delta^{18} \mathrm{O}-P_{n l}(\%)$ are the $\mathrm{O}$ isotopic composition of phosphate for the labelled and unlabelled $\mathrm{HCl}$ samples, respectively, and accordingly $\delta^{18} \mathrm{O}-\mathrm{w}_{l}(\% 0)$ and $\delta^{18} \mathrm{O}-\mathrm{w}_{n !}$ $(\%)$ the $\mathrm{O}$ isotopic signature of water used to prepare labelled and non-labelled reagents.

$\delta^{18} \mathrm{O}-P_{m i c}$ and $\delta^{18} \mathrm{O}-P_{H C l}$ per individual sample were obtained with the above-mentioned equations 11 and 12 . The means and standard deviations of $\delta^{18} \mathrm{O}-\mathrm{P}$ per pool and time point were calculated based on the values of the two individual samples. If no replicate was available $\left(\delta^{18} \mathrm{O}-P_{\text {resin }}\right.$ and $\delta^{18} \mathrm{O}-P_{\text {mic }}$ site 4 day $0, \delta^{18} \mathrm{O}-\mathrm{P}$ of inorganic $\mathrm{NaOH}-\mathrm{EDTA} \mathrm{P}$ sites 1 and 2 at both time points, and $\delta^{18} \mathrm{O}-\mathrm{P}_{\mathrm{HCl}}$ site 1 day 0 ), the value of the individual sample was reported and no standard deviation was determined.

\subsubsection{Incorporation of ${ }^{18} \mathrm{O}$ into phosphate}

Incorporation of ${ }^{18} \mathrm{O}$ into phosphate of a specific $\mathrm{P}$ pool (\%) was calculated based on the differences in $\delta^{18} \mathrm{O}$ between time points for soil water and phosphate as following (Liang and Blake, 2006a):

${ }^{18} \mathrm{O}$ incorporation $=\left(\delta^{18} \mathrm{O}-P_{\text {end }}-\delta^{18} \mathrm{O}-P_{\text {start }}\right) /\left(\delta^{18} \mathrm{O}-\mathrm{ws}_{\text {-end }}-\delta^{18} \mathrm{O}-\mathrm{Ws}\right.$ s-start $^{*}{ }^{*} 100$

Where $\delta^{18} \mathrm{O}-\mathrm{Ws}_{\mathrm{s}}$ is $\mathrm{O}$ isotopic signature of soil water and $\delta^{18} \mathrm{O}-\mathrm{P}$ is $\mathrm{O}$ isotopic signature of phosphate in the P pool at the start (day 0) and at the end of the incubation experiment (day 34). The calculations were conducted by Monte Carlo error propagation (Anderson, 1976) implementing 10 million iterations varying the $\delta^{18} \mathrm{O}$ signatures according to mean and corrected sample standard deviation. For $\delta^{18} \mathrm{O}-\mathrm{ws}_{\mathrm{s} \text {-end }}$ and $\delta^{18} \mathrm{O}-\mathrm{w}_{\mathrm{s} \text {-start }}$ standard deviations of $0.01 \%$ were assumed (Tamburini et al., 2018).

\subsection{Statistical analyses}

Statistical analyses were conducted in $\mathrm{R}$ version 3.6.0 (R Core Team, 2019). Data residuals were tested for normal distribution and homogenous variance. Some variables were log (chloroform-labile $\mathrm{C}$ and total $\mathrm{N}$ concentrations, $r / R_{\text {resin }}$ of site 2, $E_{\text {resin }}$ at day $34, p S A_{\text {resin }}$ of site 4), square root (chloroform-labile N, $P_{w}, P_{\text {mic }}$ within Hedley and total $\mathrm{C}$ concentrations, $r / R_{\text {mic }}$, $P_{i m m o}$ ) or inverse (total soil respiration, $p S A_{\text {resin }}$ ) transformed to meet assumptions of normality 
and homogeneity of variances. Analysis of variance (ANOVA) was conducted using aov (package stats version 3.6.0, R Core Team (2019)). To test site differences, the ANOVA model included site and block effect (data site+block). The block effect refers to the randomized complete block design sample set-up. To test temporal trends, analyses were conducted separately per site with sampling time point and block effect included in the ANOVA model (data time.point+block). Afterwards, Tukey's HSD (honest significant difference) post hoc tests for confidence levels 0.95 were performed with HSD.test (package agricolae version 1.31, de Mendiburu (2019)). Figures were produced using the package ggplot2 (version 3.2.0, Wickham (2009)).

\section{Results}

\subsection{Soil properties}

The soil properties varied significantly between sites (Table 2). Water holding capacity, total C and $\mathrm{N}$, chloroform-labile $\mathrm{C}$ and $\mathrm{N}, P_{\text {mic }}$, organic $\mathrm{NaOH}$-EDTA $\mathrm{P}$ and acid phosphatase activity increased from site 1 to 4 . In contrast, $P_{w}, P_{\text {resin }}$ and inorganic NaOH-EDTA P decreased from site 1 to 4 .

\section{Location Table 2}

\subsection{Soil respiration}

Total soil respiration over 36 days was ten times larger for site 4 (2500 mg C kg-1) compared to site 1 (259 $\mathrm{mg} \mathrm{C} \mathrm{kg}^{-1}$ ), with intermediate sites ranging in between and all values being significantly different from each other (Figure $2 b$ ). The proportion of total $C$ that was lost by respiration reached $1.6 \%$ in the soil of site $1,1 \%$ in site $4,0.9 \%$ in site 2 and $0.8 \%$ in site 3 . Daily soil respiration rates decreased during the incubation period, most notably for the soil of site 4 with a decrease from 99.0 to $72.8 \mathrm{mg} \mathrm{C} \mathrm{kg}^{-1} \mathrm{~d}^{-1}$ (Figure 2a).

\section{Location Figure 2}




\subsection{Phosphorus pools and the fate of radioactive phosphate}

\subsubsection{Resin phosphorus}

Resin P (Figure 3a) concentrations ( $P_{\text {resin, }} \mathrm{mg} \mathrm{P} \mathrm{kg}^{-1}$ dry soil) stayed constant in the soil of sites 3 and 4 , while they varied without clear trend for soils of sites 1 and 2 . Radioactivity recovery in the resin pool $\left(r / R_{\text {resin, }} \%\right)$ on the contrary, strongly decreased with time in all soils. $r / R_{\text {resin }}$ varied between $9 \%$ (soil of site 3 ) and $37 \%$ (soil of site 1) after 1 day of incubation and between $3 \%$ (soils of sites 3 and 4 ) and $15 \%$ (soil of site 1 ) after 34 days (Figure $3 b$ ). $r / R_{\text {resin }}$ was always smaller in the soils from the wet compared to the dry sites.

\section{Location Figure 3}

Largest amounts of isotopically exchangeable $P$ in the resin extract (Eresin, Figure 4) were observed for sites 3 and 2, intermediate amounts for site 2, and the lowest amounts for site 4 . The amounts increased over time for all sites. Each of these curves could be described with the equation $E_{\text {resin }(t)}=E_{\text {resin( }(1)}{ }^{*} t^{n}$ (with $\mathrm{t}$ being the incubation time expressed in days, $E_{\text {resin( }(1)}$ the amount of $\mathrm{P}$ isotopically exchangeable after one day, Eresin(t) the amount of $\mathrm{P}$ isotopically exchangeable after $t$ days and $n$ an empirical parameter) reaching $r^{2}$ values higher than 0.95 .

\section{Location Figure 4}

\subsubsection{Microbial phosphorus}

Microbial $\mathrm{P}$ concentrations (Figure $5 \mathrm{a}, P_{\text {mic }}, \mathrm{mg} \mathrm{P} \mathrm{kg}^{-1}$ dry soil) remained constant in the soil of sites 3 and 4 and varied without clear trend for sites 1 and 2 . The lowest $P_{\text {mic }}$ concentrations were observed in the soil of site 1 , and the highest in the soil of site 4 . Radioactivity recovery in the microbial biomass $\left(r / R_{m i c}, \%\right)$ (Figure $\left.5 b\right)$ was low $(<10 \%)$ and variable in the soils of all sites. It was often not possible to measure $r / R_{\text {mic }}$ in the soil of site 1 due to the very small size of the microbial $\mathrm{P}$ pool. The radioactive data of microbial $\mathrm{P}$ of the soil from site 1 are therefore not discussed. A significant decrease over time was observed in the soil of site 2 with $r / R$ mic ranging from 1 to $0.2 \%$ of the added ${ }^{32} \mathrm{P}$. 
A high proportion of introduced ${ }^{32} \mathrm{P}$ was not detected in either the resin or the microbial $\mathrm{P}$ pool already after 1 day of incubation (from $62.0 \%$ for site 1 to $89.3 \%$ for site 3 ), indicating a fast disappearance of this tracer towards other P pools.

\section{Location Figure 5}

Assuming that microorganisms took up their $\mathrm{P}$ from the resin $\mathrm{P}$ pool and knowing the specific activity of the resin and microbial pools, we could calculate the amount of $P$ in the microbial biomass derived from the resin pool, (Figure 6, $P_{\text {immo, }} \mathrm{mg} \mathrm{P} \mathrm{kg}^{-1}$ dry soil), which is an estimation for the gross $P$ immobilisation. This amount remained low and variable in the soil of site 2 (below $5 \mathrm{mg} \mathrm{P} \mathrm{kg}^{-1}$ dry soil), while it increased significantly with time in the soils of sites 3 and 4 reaching $20 \mathrm{mg} \mathrm{P} \mathrm{kg}^{-1}$ dry soil at the last sampling point of the soil of site 4 . Gross $\mathrm{P}$ immobilisation ranged between $2 \%$ of microbial $P$ for the first sampling time point of site 4 (2.0 $\mathrm{mg} \mathrm{P} \mathrm{kg}^{-1}$ for $P_{\text {immo }}$ compared to $109.5 \mathrm{mg} \mathrm{P} \mathrm{kg}^{-1}$ for $P_{\text {mic }}$ ) and $27 \%$ for the sampling time point at 14 days of site 3 (15.6 $\mathrm{mg} \mathrm{P} \mathrm{kg}^{-1}$ for $P_{\text {immo }}$ compared to $58.5 \mathrm{mg} \mathrm{P} \mathrm{kg}^{-1}$ for $P_{\text {mic }}$ ).

\section{Location Figure 6}

\subsection{Oxygen isotopes}

\subsubsection{Oxygen isotopic signatures}

The addition of ${ }^{18} \mathrm{O}$ enriched water resulted in increased $\mathrm{O}$ isotopic signatures of soil water $\left(\delta^{18} O-w_{s}\right)$ after 34 days of incubation for all sites (Table 3$)$. Consequently, the calculated equilibrium values between ${ }^{18} \mathrm{O}$ in water and ${ }^{18} \mathrm{O}$ in phosphate were between 1.4 to 4 times higher at the final sampling point compared to the value calculated at day 0 of the incubation. Taking the metabolic water into consideration led to lower equilibrium values.

\section{Location Table 3}

The $\delta^{18} \mathrm{O}-P_{\text {resin }}$ and $\delta^{18} \mathrm{O}-P_{\text {mic }}$ of the soils of each site increased by several permil during the incubation, while the other $\mathrm{P}$ pools did not show any increase in $\delta^{18} \mathrm{O}-\mathrm{P}$ (Table 3). The $\delta^{18} \mathrm{O}-\mathrm{P}$ of none of the $\mathrm{P}$ pools reached equilibrium with $\delta^{18} \mathrm{O}-\mathrm{w}_{s}$ or with $\delta^{18} \mathrm{O}-\mathrm{w}_{\mathrm{s}+\mathrm{m}}$ during the incubation. 


\subsubsection{Incorporation of ${ }^{18} \mathrm{O}$ into soil phosphorus pools}

Incorporation of ${ }^{18} \mathrm{O}$ from enriched water into phosphate was observable in the resin and microbial P pools, but not in inorganic or organic $\mathrm{NaOH}$-EDTA P or $\mathrm{HCl} P$ (Table 4). In the resin and microbial $\mathrm{P}$ pools, approximately 1 out of $4 \mathrm{O}$ atoms per phosphate was exchanged during the incubation in the soils of sites 1 to 3 . The soil of the wettest site showed higher exchange rates than the other sites, particularly in resin $\mathrm{P}\left(41 \%{ }^{18} \mathrm{O}\right.$ incorporation).

\section{Location Table 4}

\section{Discussion}

In the introduction, we considered three types of processes controlling P dynamics in soils: those that maintain the bond between $\mathrm{P}$ and $\mathrm{O}$ and transfer phosphate from one pool to another (category I processes), those that involve cleavage of the P-O bond and transfer phosphate from one pool to another (category lla processes), and those that involve cleavage of the P-O bond but do not transfer phosphate from one pool to another (category $\mathrm{llb}$ processes). We discuss how far the use of $\mathrm{P}$ and $\mathrm{O}$ isotopes allows to assess these three types of processes and their roles in soil $\mathrm{P}$ dynamics.

\subsection{Category I pathways: phosphates move as intact units}

The use of ${ }^{32} \mathrm{P}$ allowed assessing the amount of soil $\mathrm{P}$ that was isotopically exchanged over the time of incubation (Eresin). The fact that the resin P pool size did not vary significantly with time in each soil, while the fraction of radioactive $\mathrm{P}$ in the resin extracts significantly decreased, confirms that the main mechanism controlling ${ }^{32} \mathrm{P}$ losses from the resin $\mathrm{P}$ pool was isotopic exchange rather than a net change in pool size. Soil organic $\mathrm{P}$ mineralisation could have contributed to the dilution of the added ${ }^{32} \mathrm{P}$, but it was probably not a dominant mechanism. If we assume that $\mathrm{C}$ and $\mathrm{P}$ are stoichiometrically mineralised, the amount of organic $\mathrm{P}$ mineralised during the incubation would be equal to the ratio between the amount of $C$ mineralised during the incubation to total $C$ multiplied by organic $P$ (Achat et al., 2009). The measured organic $\mathrm{NaOH}-\mathrm{EDTA} P$ was set as organic $\mathrm{P}$. The amount of mineralised $\mathrm{C}$ was 
derived from $\mathrm{C}$ emitted as $\mathrm{CO}_{2}$ corrected by the microbial $\mathrm{C}$ assimilation efficiency, which was assumed to be 0.4 according to Murphy et al. (2003). This calculation suggests that the amount of mineralised organic $\mathrm{P}$ would range between 14 for the soil of site 1 and $41 \mathrm{mg} \mathrm{P} \mathrm{kg}^{-1} \mathrm{dry}$ soil for the soil of site 4, ergo would reach values smaller or equal to the standard deviations observed for $E_{\text {resin }}$ after 34 days of incubation. Moreover, the changes in $E_{\text {resin }}$ with time can be described for each soil with a simple $\log / \log$ relation $\left(E_{\text {resin( }(t)}=E_{\text {resin( }(1)}{ }^{*} t^{n}\right)$, which is similar to the equation used by Fardeau and Zapata (2002) to describe the changes in soil isotopically exchangeable $\mathrm{P}$ with time. Isotopic exchange is controlled both by sorption and desorption and by transfer of $P$ from the charged surface to the bulk solution by diffusion and can, therefore, be assigned to the category I processes. The large amounts of soil P isotopically exchangeable with resin P show the importance of category I processes in these soils. Maertens et al. (2004) observed the same type of relationship between $E_{\text {resin }}$ and incubation time. However, in their work, the increase of Eresin with time was several-fold smaller compared to our results. This difference is probably due to the difference in soil types and the difference in total P content as Maertens et al. (2004) presented results on a lixisol and a ferralsol from Kenya, which contained less amorphous minerals and less total $\mathrm{P}$ than our andosols. The high rate of $\mathrm{P}$ exchangeability found in our andosols confirms the results of Helfenstein et al. (2018) and is consistent with the presence of high amounts of amorphous minerals in these soils (Chadwick et al., 2003).

The use of ${ }^{32} \mathrm{P}$ allowed the quantification of the amount of $\mathrm{P}$ derived from the resin pool that was taken up by microorganisms (gross $\mathrm{P}$ immobilisation, $P_{\text {immo}}$ ). These microbial processes probably involved pathways in which phosphate was taken up as a unit (category I processes) and processes during which an O-P bond was cleaved (category lla and Ilb processes), for example, if $\mathrm{P}$ was taken up after extracellular enzymatic hydrolysis. If we do not consider the soil from site 1 on which a substantial amount of data was missing due to the very low microbial $\mathrm{P}$ content, the amount of $\mathrm{P}$ derived from the resin incorporated in the microbial biomass was significantly larger for the soils of sites 3 and 4 than for the soil of site 2 , and this amount increased with time for the soils of sites 3 and 4 . The highest $P$ uptake rate observed in the 
soil of site 4 was in agreement with the highest rate of $\mathrm{CO}_{2}$ emission from this soil and the high microbial biomass. Bünemann et al. (2012) and Pistocchi et al. (2018) also used P radioisotopes for the estimation of gross $\mathrm{P}$ immobilisation rates during incubation experiments. Contrary to our approach, their calculations are based on the changes in specific activity in water extracts and not the changes in specific activity in resin extracts. Nevertheless, they observed higher gross $\mathrm{P}$ immobilisation (between 40 and $50 \mathrm{mg} \mathrm{P} \mathrm{kg}^{-1}$ soil after 11 days in Pistocchi et al. (2018) and between 36 and $49 \mathrm{mg} \mathrm{P} \mathrm{kg}^{-1}$ soil after 32 days in Bünemann et al. (2012)) compared to our study (between 5 and $20 \mathrm{mg} \mathrm{P} \mathrm{kg}^{-1}$ soil after 34 days). Since we have not used a correction factor $\left(k_{P}\right)$ for calculating microbial $P$ content, the fluxes of $P$ through the microbial biomass are underestimated. Nevertheless, even if we applied a kp factor of 0.8 as in Olander and Vitousek (2005), the resulting values for gross P immobilisation after 34 days of incubation would remain well below the $E_{\text {resin }}$ values. For example, for the soil of site $4 \mathrm{kP}$ corrected gross $\mathrm{P}$ immobilisation would only reach $9 \%$ of the respective $E_{\text {resin. }}$

Our results contrast with those presented by Olander and Vitousek (2005), who showed that microbial control on $\mathrm{P}$ uptake from the solution was at least as strong as the sorption control in a Hawaiian chronosequence after 48 hours of incubation. But, these results are difficult to compare to ours because i) they estimated available $\mathrm{P}$ with the Bray I extractant while we used anion exchange resins, and ii) they added $10 \mu \mathrm{g} \mathrm{P} \mathrm{g}{ }^{-1}$ soil which was a significant input compared to the low amounts of P extracted by the Bray I method from the non-treated soils (smaller than $4.5 \mu \mathrm{g} \mathrm{P} \mathrm{g}{ }^{-1}$ ). We added no ${ }^{31} \mathrm{P}$ with the ${ }^{32} \mathrm{P}$ to minimise changes in chemical equilibrium between the soil and the solution. However, based on the assumption that $P$ extracted by the Bray I method and the resin should target a similar P pool (van Raij et al., 2009), we assume that the soils studied in our work (27.6 to $69.3 \mathrm{mg}$ resin $\mathrm{P} \mathrm{kg}^{-1}$, Table 2) had a higher P availability than those studied by Olander and Vitousek (2005) (0.27 to $4.32 \mathrm{mg}$ Bray I P kg-1). Our results together with those presented by Olander and Vitousek (2005), by Schneider et al. (2017), and by Pistocchi et al. (2017) suggest that the proportion of P cycling through the microbial biomass increases with decreasing $P$ availability. 


\subsection{Category II pathways: the bond between oxygen and phosphate atoms is cleaved}

The $\delta^{18} \mathrm{O}-\mathrm{P}$ of the different $\mathrm{P}$ pools before labelling with ${ }^{18} \mathrm{O}$ enriched water (Table 3 ) were resembling those found for these soils by Helfenstein et al. (2018).

Although the $\delta^{18} O-P_{\text {mic }}$ had increased during the 34 days of incubation, in none of the soils equilibrium with the $\delta^{18} \mathrm{O}-w_{s}$ was reached, even when the metabolic water was considered in the calculation of the equilibrium values. This increase shows that ${ }^{18} \mathrm{O}$ had been incorporated into microbial P and that the P-O bond of phosphate had been broken. Thus, phosphate had undergone processes of categories Ila and/or Ilb. But the fact that the equilibrium was not reached shows also that the $\mathrm{O}$ bound to $\mathrm{P}$ in the microbial biomass had not yet been entirely turned over (category $\mathrm{llb}$ process). A complete turnover of $\mathrm{O}$ in phosphate in the presence of pyrophosphatase and $\mathrm{Mg}$ was observed within a few hours in sterile systems (Chang and Blake, 2015; von Sperber et al., 2017b). However, it is probable that in a heterogeneous medium like soil, within which different types of microorganisms cohabit (Peay et al., 2017), a longer time will be required for $\mathrm{O}$ atoms of phosphate to equilibrate with the $\mathrm{O}$ atoms of water present within the soil microorganisms. At the end of incubation, in our soils, the mean incorporation of ${ }^{18} \mathrm{O}$ into microbial $\mathrm{P}$ was non-linearly correlated with the mean amount of $\mathrm{C}$ emitted as $\mathrm{CO}_{2}\left(\mathrm{r}^{2}=0.919\right)$. This agrees with Middelboe and Saaby Johansen (1992) and Melby et al. (2013a), who showed that the de-labelling of ${ }^{18} \mathrm{O}$ from ${ }^{18} \mathrm{O}$ labelled $\mathrm{PO}_{4}$ was correlated to soil microbial activity.

The resin and microbial $P$ pools had similar $\delta^{18} O-P$ signatures in the soils of the sites 1,2 and 3 at day 0 and at the end of the incubation, whereas in the soil of site 4 the $\delta^{18} O-P_{\text {mic }}$ was lower than $\delta^{18} \mathrm{O}-\mathrm{P}_{\text {resin }}$ at both time points. This suggests a constant and rapid turnover of $\mathrm{P}$ between the resin and the microbial pool for the soils of sites 1,2 , and 3 . The resin and inorganic $\mathrm{NaOH}$ EDTA P pools were expected to show similar $\delta^{18} \mathrm{O}-\mathrm{P}$ signatures, as $\mathrm{NaOH} \mathrm{P}$ exchanges relatively rapidly with the $P$ in solution, except in systems that contain $P$ in crystallized minerals such as vivianite (Frossard et al., 1996; Helfenstein et al., 2018). However, this was not the 
case for the soils of sites 1 and 2 . The differences can be possibly explained by i) the fact that 34 days were probably not sufficient for complete equilibration between the different inorganic $\mathrm{P}$ pools, and ii) the presence of different forms of inorganic $\mathrm{P}$ species extracted by $\mathrm{NaOH}$ EDTA. The first explanation agrees with the fact that only 21 to $56 \%$ of the inorganic $\mathrm{NaOH}$ EDTA $P$ was exchangeable after 34 days of incubation. In accordance, the estimated mean residence time of $\mathrm{P}$ in the $\mathrm{NaOH} \mathrm{P}$ pool of Andosols is around six months, substantially longer than the duration of our incubation experiment (Helfenstein et al., 2020). More information on the inorganic $\mathrm{P}$ species extracted by $\mathrm{NaOH}-\mathrm{EDTA}$ would be necessary to provide support for the second explanation.

The soil of site 4 behaved differently compared to the other soils as its $\delta^{18} O-P_{\text {mic }}$ was much lower than its $\delta^{18} \mathrm{O}-P_{\text {resin }}$ and a higher proportion of ${ }^{18} \mathrm{O}$ was incorporated in the phosphates of the microbial and of the resin pools. The high rate of incorporation of ${ }^{18} \mathrm{O}$ in the microbial pool reflects the high microbial activity (shown also by the high $\mathrm{CO}_{2}$ emission and high $\mathrm{P}$ uptake by microbes from the resin pool). The lower and far from equilibrium $\delta^{18} \mathrm{O}-P_{\text {mic }}$ compared to $\delta^{18} \mathrm{O}-$ Presin seems to suggest the presence of different groups of microorganisms, all of them extractable by hexanol. The first group of organisms is active in uptake and release of phosphate to the soil solution and exchanges $\mathrm{O}$ between phosphate and water. The second group, on the other hand, is probably in a more dormant status and characterised by a lower $\delta^{18} \mathrm{O}-\mathrm{P}$. This group interacts less with the soil solution and does not actively exchange $\mathrm{O}$ between phosphate and water (Chen et al., 2019).

\section{Conclusions}

Radioactive $P$ is an established tracer to assess the $P$ fluxes from one soil compartment to another, whereas changes in the isotopic composition of $\mathrm{O}$ associated with phosphate are investigated to provide information on the impact of phosphatase activity on soil $\mathrm{P}$ dynamics. In this paper, we showed that the use of ${ }^{32} \mathrm{P}$ and ${ }^{18} \mathrm{O}$ in parallel experiments generated results that reinforced each other. For instance, the fact that at the end of the incubation only 21 to $56 \%$ of the $\mathrm{NaOH}$-EDTA P was measured as isotopically exchangeable agreed with the fact 
that the $\delta^{18} \mathrm{O}-\mathrm{P}$ of the resin pool was not equal to the $\delta^{18} \mathrm{O}-\mathrm{P}$ of the $\mathrm{NaOH}$-EDTA pool. With a longer incubation time, we might reach $100 \%$ exchangeability in the $\mathrm{NaOH}-E D T A P$ pool and thus, the $\delta^{18} \mathrm{O}-\mathrm{P}$ of this pool and of the resin pool would have approached similar values. Furthermore, the use of ${ }^{32} \mathrm{P}$ allowed to quantify the fraction of $\mathrm{P}$ derived from the resin pool and taken up by microorganisms, while changes of the $\delta^{18} \mathrm{O}-\mathrm{P}$ in microorganisms allowed to detect the incorporation of $\mathrm{O}$ in phosphate within microorganisms, both aspects being linked to microbial activity. In two cases the $\delta^{18} \mathrm{O}-\mathrm{P}$ allowed to follow processes that were not observable with ${ }^{32} \mathrm{P}$ : i) the incorporation of ${ }^{18} \mathrm{O}$ in the resin $\mathrm{P}$ pool suggested that either some of this $\mathrm{P}$ had been released by enzymatic hydrolysis from organic $\mathrm{P}$ or that it has been released from microorganisms in which the $\mathrm{O}$ associated with $\mathrm{P}$ had been turned over, and ii) the difference between $\delta^{18} \mathrm{O}-\mathrm{P}$ of the resin and the microbial pool at the end of the incubation in the soil of site 4 suggested that this soil could contain groups of microorganisms exhibiting different levels of activities. Further microbiological analyses would be needed to support this last hypothesis. In any case, the results of this study confirm preceding research which showed that $\delta^{18} \mathrm{O}-\mathrm{P}$ cannot be used to quantify the transfer of $\mathrm{P}$ from one pool to the next. Nevertheless, we conclude that the two tracers provide complementary information that helps to better understand the soil $\mathrm{P}$ dynamics.

\section{Acknowledgements}

We would like to acknowledge Parker and Ponholo Ranches and Kamehameha Schools for providing access to the research sites. We further thank Dr. Laurie Schönholzer and Monika Macsai for support in setting up the experiment and for conducting analysis; Lilian Gasser, Andreas Psimopoulos and Nina Roth for statistical support; and Prof. Dr. Beat Zehnder for discussions. Further, we are thankful for the constructive comments of three anonymous reviewers. This work was funded by the Swiss National Science Foundation [SNF project 162422]. The master thesis of Maja Siegenthaler was supported by the Walter Hochstrasser Stiftung. 


\section{References}

Achat, D.L., Bakker, M.R., Augusto, L., Saur, E., Dousseron, L., Morel, C., 2009. Evaluation of the phosphorus status of P-deficient podzols in temperate pine stands: combining isotopic dilution and extraction methods. Biogeochemistry 92, 183-200.

Alef, K., 1995. Soil Respiration, In: Alef, K., Nannipieri, P. (Eds.), Methods in Soil Microbiology and Biochemistry. Academic Press Inc., San Diego, pp. 214-215.

Anderson, G.M., 1976. Error propagation by the Monte Carlo method in geochemical calculations. Geochimica Et Cosmochimica Acta 40, 1533-1538.

Blake, R.E., O'Neil, J.R., Surkov, A.V., 2005. Biogeochemical cycling of phosphorus: Insights from oxygen isotope effects of phosphoenzymes. American Journal of Science 305, 596-620.

Bünemann, E.K., Augstburger, S., Frossard, E., 2016. Dominance of either physicochemical or biological phosphorus cycling processes in temperate forest soils of contrasting phosphate availability. Soil Biology \& Biochemistry 101, 85-95.

Bünemann, E.K., Oberson, A., Liebisch, F., Keller, F., Annaheim, K.E., Huguenin-Elie, O., Frossard, E., 2012. Rapid microbial phosphorus immobilization dominates gross phosphorus fluxes in a grassland soil with low inorganic phosphorus availability. Soil Biology \& Biochemistry 51, 84-95.

Bünemann, E.K., Steinebrunner, F., Smithson, P.C., Frossard, E., Oberson, A., 2004. Phosphorus dynamics in a highly weathered soil as revealed by isotopic labeling techniques. Soil Science Society of America Journal 68, 1645-1655.

Chadwick, O.A., Gavenda, R.T., Kelly, E.F., Ziegler, K., Olson, C.G., Elliott, W.C., Hendricks, D.M., 2003. The impact of climate on the biogeochemical functioning of volcanic soils. Chemical Geology 202, 195-223. 
Chang, S.J., Blake, R.E., 2015. Precise calibration of equilibrium oxygen isotope fractionations between dissolved phosphate and water from 3 to 37 degrees C. Geochimica Et Cosmochimica Acta 150, 314-329.

Chen, J., Seven, J., Zilla, T., Dippold, M.A., Blagodatskaya, E., Kuzyakov, Y., 2019. Microbial $\mathrm{C}: \mathrm{N}: \mathrm{P}$ stoichiometry and turnover depend on nutrients availability in soil: $\mathrm{A}{ }^{14} \mathrm{C},{ }^{15} \mathrm{~N}$ and ${ }^{33} \mathrm{P}$ triple labelling study. Soil Biology and Biochemistry 131, 206-216.

de Mendiburu, F., 2019. gricolae: Statistical Procedures for Agricultural Research.

Fardeau, J.C., Zapata, F., 2002. Phosphorus fertility recapitalization of nutrient-depleted tropical acid soils with reactive phosphate rock: An assessment using the isotopic exchange technique. Nutrient Cycling in Agroecosystems 63, 69-79.

Frossard, E., Achat, D.L., Bernasconi, S.M., Bunemann, E.K., Fardeau, J.C., Jansa, J., Morel, C., Rabeharisoa, L., Randriamanantsoa, L., Sinaj, S., Tamburini, F., Oberson, A., 2011. The Use of Tracers to Investigate Phosphate Cycling in Soil-Plant Systems, In: Bunemann, E.K., Oberson, A., Frossard, E. (Eds.), Phosphorus in Action: Biological Processes in Soil Phosphorus Cycling. Springer-Verlag Berlin, Berlin, pp. 59-91.

Frossard, E., Condron, L.M., Oberson, A., Sinaj, S., Fardeau, J.C., 2000. Processes governing phosphorus availability in temperate soils. Journal of Environmental Quality 29, 15-23.

Frossard, E., Sinaj, S., Dufour, P., 1996. Phosphorus in urban sewage sludges as assessed by isotopic exchange. Soil Science Society of America Journal 60, 179-182.

Giambelluca, T.W., Chen, Q., Frazier, A.G., Price, J.P., Chen, Y.L., Chu, P.S., Eischeid, J.K., Delparte, D.M., 2013. Online rainfall atlas of Hawai'i. Bulletin of the American Meteorological Society 94, 313-316.

Hedley, M.J., Stewart, J.W.B., Chauhan, B.S., 1982. Changes in inorganic and organic soilphosphorus fractions induced by cultivation practices and by laboratory incubations. Soil Science Society of America Journal 46, 970-976. 
Helfenstein, J., Pistocchi, C., Oberson, A., Tamburini, F., Goll, D.S., Frossard, E., 2020. Estimates of mean residence times of phosphorus in commonly-considered inorganic soil phosphorus pools. Biogeosciences 17, 441-454.

Helfenstein, J., Tamburini, F., von Sperber, C., Massey, M.S., Pistocchi, C., Chadwick, O.A., Vitousek, P.M., Kretzschmar, R., Frossard, E., 2018. Combining spectroscopic and isotopic techniques gives a dynamic view of phosphorus cycling in soil. Nature Communications 9, 19.

Jaisi, D.P., Blake, R.E., Kukkadapu, R.K., 2010. Fractionation of oxygen isotopes in phosphate during its interactions with iron oxides. Geochimica Et Cosmochimica Acta 74, 1309-1319.

Kouno, K., Tuchiya, Y., Ando, T., 1995. Measurement of soil microbial biomass-phosphorus by anion-exchange membrane method. Soil Biology \& Biochemistry 27, 1353-1357.

Kreuzer-Martin, H.W., Ehleringer, J.R., Hegg, E.L., 2005. Oxygen isotopes indicate most intracellular water in log-phase Escherichia coli is derived from metabolism. Proceedings of the National Academy of Sciences of the United States of America 102, 17337-17341.

Larsen, S., Middelboe, V., Saaby Johansen, H., 1989. The fate of O-18 labeled phosphate in soil plant-systems. Plant and Soil 117, 143-145.

Li, H., Yu, C., Wang, F., Chang, S.J., Yao, J., Blake, R.E., 2016. Probing the metabolic water contribution to intracellular water using oxygen isotope ratios of $\mathrm{PO}_{4}$. Proceedings of the National Academy of Sciences of the United States of America 113, 5862-5867.

Liang, Y., Blake, R.E., 2006a. Oxygen isotope composition of phosphate in organic compounds: Isotope effects of extraction methods. Organic Geochemistry 37, 1263-1277.

Liang, Y., Blake, R.E., 2006b. Oxygen isotope signature of P-i regeneration from organic compounds by phosphomonoesterases and photooxidation. Geochimica Et Cosmochimica Acta 70, 3957-3969. 
Liang, Y., Blake, R.E., 2007. Oxygen isotope fractionation between apatite and aqueous-phase phosphate: $20-45^{\circ} \mathrm{C}$. Chemical Geology $238,121-133$.

Liang, Y., Blake, R.E., 2009. Compound- and enzyme-specific phosphodiester hydrolysis mechanisms revealed by $\delta^{18} \mathrm{O}$ of dissolved inorganic phosphate: Implications for marine $\mathrm{P}$ cycling. Geochimica Et Cosmochimica Acta 73, 3782-3794.

Maertens, E., Thijs, A., Smolders, E., Degryse, F., Cong, P.T., Merckx, R., 2004. An anion resin membrane technique to overcome detection limits of isotopically exchanged $P$ in $P$ sorbing soils. European Journal of Soil Science 55, 63-69.

Marx, M.C., Wood, M., Jarvis, S.C., 2001. A microplate fluorimetric assay for the study of enzyme diversity in soils. Soil Biology \& Biochemistry 33, 1633-1640.

McLaren, T.I., Smernik, R.J., McLaughlin, M.J., Doolette, A.L., Richardson, A.E., Frossard, E., 2019. The chemical nature of soil organic phosphorus - A critical review and global compilation of quantitative data. Advances in Agronomy, in press.

Melby, E.S., Soldat, D.J., Barak, P., 2013a. Biological decay of O-18-labeled phosphate in soils. Soil Biology \& Biochemistry 63, 124-128.

Melby, E.S., Soldat, D.J., Barak, P., 2013b. Preferential Soil Sorption of Oxygen-18-Labeled Phosphate. Communications in Soil Science and Plant Analysis 44, 2371-2377.

Middelboe, V., Saaby Johansen, H., 1992. Facile oxygen-18 labelling of phosphate and its delabelling under various conditions. International Journal of Radiation Applications and Instrumentation. Part A. Applied Radiation and Isotopes 43, 1167-1168.

Moir, J.O., Tiessen, H., 2007. Characterization of Available P by Sequential Extraction, Soil Sampling and Methods of Analysis, Second Edition. CRC Press.

Murphy, D.V., Recous, S., Stockdale, E.A., Fillery, I.R.P., Jensen, L.S., Hatch, D.J., Goulding, K.W.T., 2003. Gross nitrogen fluxes in soil: Theory, measurement and application of N-15 pool 
dilution techniques, In: Sparks, D.L. (Ed.), Advances in Agronomy, Vol 79. Elsevier Academic Press Inc, San Diego, pp. 69-118.

Oberson, A., Joner, E.J., 2005. Microbial turnover of phosphorus in soil, In: Turner, B.L., Frossard, E., Baldwin, D.S. (Eds.), Organic phosphorus in the environment, CABI Publishing, Wallingford, pp. 133-164.

Ohno, T., Zibilske, L.M., 1991. Determination of low concentrations of phosphorus in soil extracts using malachite green. Soil Science Society of America Journal 55, 892-895.

Olander, L.P., Vitousek, P.M., 2005. Short-term controls over inorganic phosphorus during soil and ecosystem development. Soil Biology \& Biochemistry 37, 651-659.

Orlowski, N., Frede, H.G., Bruggemann, N., Breuer, L., 2013. Validation and application of a cryogenic vacuum extraction system for soil and plant water extraction for isotope analysis. Journal of Sensors and Sensor Systems 2, 179-193.

Peay, K.G., von Sperber, C., Cardarelli, E., Toju, H., Francis, C.A., Chadwick, O.A., Vitousek, P.M., 2017. Convergence and contrast in the community structure of Bacteria, Fungi and Archaea along a tropical elevation-climate gradient. FEMS Microbiology Ecology 93, article 5. Pfahler, V., Tamburini, F., Bernasconi, S.M., Frossard, E., 2017. A dual isotopic approach using radioactive phosphorus and the isotopic composition of oxygen associated to phosphorus to understand plant reaction to a change in P nutrition. Plant Methods 13, article 75.

Pistocchi, C., Mészáros, É., Tamburini, F., Frossard, E., Bünemann, E.K., 2018. Biological processes dominate phosphorus dynamics under low phosphorus availability in organic horizons of temperate forest soils. Soil Biology and Biochemistry 126, 64-75.

Pistocchi, C., Tamburini, F., Gruau, G., Ferhi, A., Trevisan, D., Dorioz, J.M., 2017. Tracing the sources and cycling of phosphorus in river sediments using oxygen isotopes: Methodological adaptations and first results from a case study in France. Water Research 111, 346-356. 
Poll, C., Ingwersen, J., Stemmer, M., Gerzabek, M.H., Kandeler, E., 2006. Mechanisms of solute transport affect small-scale abundance and function of soil microorganisms in the detritusphere. European Journal of Soil Science 57, 583-595.

R Core Team, 2019. R: A language and environment for statistical computing. R Foundation for Statistical Computing, Vienna, Austria.

Saaby Johansen, H., Middelboe, V., Larsen, S., 1991. Delabelling of ${ }^{18} \mathrm{O}$ enriched phosphate added to soil as a function of biological activity in the soil. IAEA, International Atomic Energy Agency (IAEA).

Scheerer, U., Netzer, F., Bauer, A.F., Herschbach, C., 2019. Measurements of O-18-P-i uptake indicate fast metabolism of phosphate in tree roots. Plant Biology $21,565-570$.

Schneider, K.D., Voroney, R.P., Lynch, D.H., Oberson, A., Frossard, E., Bünemann, E.K., 2017. Microbially-mediated $P$ fluxes in calcareous soils as a function of water-extractable phosphate. Soil Biology and Biochemistry 106, 51-60.

Spengler, S.R., Garcia, M.O., 1988. Geochemistry of the hawi lavas, Kohala volcano, Hawaii. Contributions to Mineralogy and Petrology 99, 90-104.

Tamburini, F., Bernasconi, S.M., Angert, A., Weiner, T., Frossard, E., 2010. A method for the analysis of the delta $\mathrm{O}-18$ of inorganic phosphate extracted from soils with $\mathrm{HCl}$. European Journal of Soil Science 61, 1025-1032.

Tamburini, F., Pfahler, V., Bunemann, E.K., Guelland, K., Bernasconi, S.M., Frossard, E., 2012. Oxygen Isotopes Unravel the Role of Microorganisms in Phosphate Cycling in Soils. Environmental Science \& Technology 46, 5956-5962.

Tamburini, F., Pfahler, V., von Sperber, C., Frossard, E., Bernasconi, S.M., 2014. Oxygen Isotopes for Unraveling Phosphorus Transformations in the Soil-Plant System: A Review. Soil Science Society of America Journal 78, 38-46. 
Tamburini, F., Pistocchi, C., Helfenstein, J., Frossard, E., 2018. A method to analyse the isotopic composition of oxygen associated with organic phosphorus in soil and plant material. European Journal of Soil Science 69, 816-826.

van Raij, B., Cantarella, H., Quaggio, J., Prochnow, L., 2009. lon exchange resin for assessing phosphorus availability in soils. Better Crops 93, 23-25.

Vance, E.D., Brookes, P.C., Jenkinson, D.S., 1987. An extraction method for measuring soil microbial biomass-C. Soil Biology \& Biochemistry 19, 703-707.

Vitousek, P.M., Chadwick, O.A., 2013. Pedogenic thresholds and soil process domains in basalt-derived soils. Ecosystems 16, 1379-1395.

von Sperber, C., Chadwick, O.A., Casciotti, K.L., Peay, K.G., Francis, C.A., Kim, A.E., Vitousek, P.M., 2017a. Controls of nitrogen cycling evaluated along a well-characterized climate gradient. Ecology 98, 1117-1129.

von Sperber, C., Kries, H., Tamburini, F., Bernasconi, S.M., Frossard, E., 2014. The effect of phosphomonoesterases on the oxygen isotope composition of phosphate. Geochimica Et Cosmochimica Acta 125, 519-527.

von Sperber, C., Lewandowski, H., Tamburini, F., Bernasconi, S.M., Amelung, W., Frossard, E., 2017b. Kinetics of enzyme-catalysed oxygen isotope exchange between phosphate and water revealed by Raman spectroscopy. Journal of Raman Spectroscopy 48, 368-373.

Wickham, H., 2009. ggplot2: Elegant Graphics for Data Analysis. Springer Publishing Company, Incorporated. 
Accepted manuscript of Siegenthaler et al. (2020): https://doi.org/10.1016/j.soilbio.2020.107920

\section{Tables}

Table 1: Overview of the experimental schedule during the incubation.

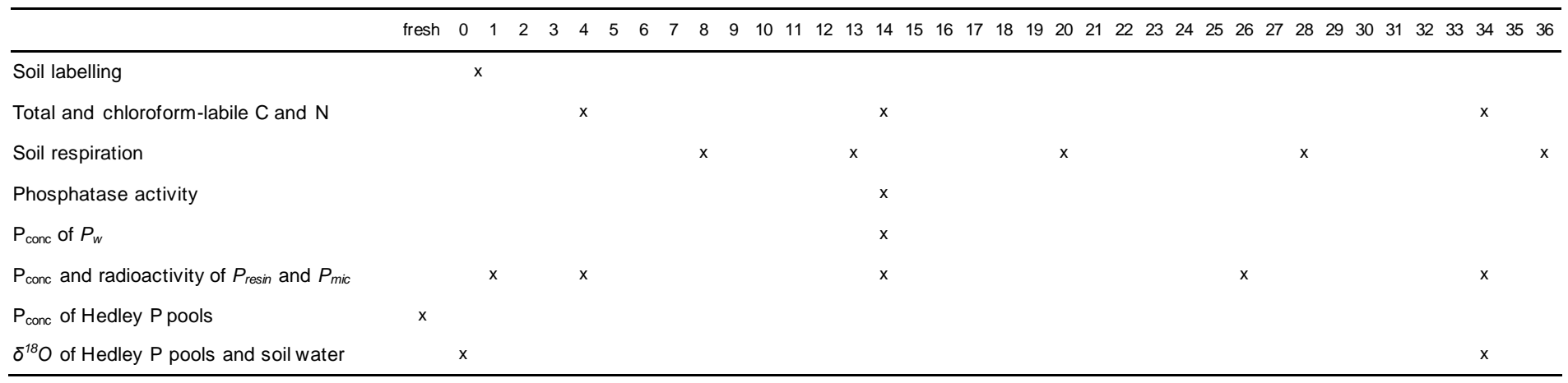


Table 2: Selected properties of studied soils: water holding capacity (WHC); nutrient (carbon, nitrogen and phosphorus) concentrations; $\mathrm{pH}$ and acid potential phosphatase activities. Means and corrected sample standard deviations per site, different letters denote significant differences $(P \leq 0.05)$ among sites.

\begin{tabular}{|c|c|c|c|c|c|}
\hline & Unit & Site 1 & Site 2 & Site 3 & Site 4 \\
\hline Maximal water holding capacity $(\mathrm{WHC})^{\#}$ & $\mathrm{~g} \mathrm{H}_{2} \mathrm{O} \mathrm{g}^{-1}$ & 0.62 & 1.18 & 2.24 & 3.36 \\
\hline Chloroform-labile C $\left(C_{c h l}\right)^{\# \#}$ & $\mathrm{mgC} \mathrm{kg}{ }^{-1}$ & $90 \pm 24^{d}$ & $228 \pm 40^{c}$ & $416 \pm 85^{b}$ & $769 \pm 101^{a}$ \\
\hline Total C\#\# & $\mathrm{gC} \mathrm{kg}^{-1}$ & $16 \pm 1^{d}$ & $63 \pm 1^{c}$ & $170 \pm 3^{b}$ & $239 \pm 3^{a}$ \\
\hline Chloroform-labile $\mathrm{N}\left(\mathrm{N}_{\text {chl }}\right)^{\# \#}$ & $\mathrm{mg} \mathrm{N} \mathrm{kg}^{-1}$ & $10 \pm 5^{c}$ & $43 \pm 19^{b}$ & $40 \pm 21^{b}$ & $107 \pm 41^{a}$ \\
\hline Total N \#\# & $\mathrm{g} \mathrm{N} \mathrm{kg}^{-1}$ & $1.5 \pm 0.0^{d}$ & $6.1 \pm 0.1^{c}$ & $12.8 \pm 0.2^{b}$ & $18.6 \pm 0.3^{a}$ \\
\hline Water extractable $\mathrm{P}\left(P_{w}\right)^{\ldots \ldots}$ & $\mathrm{mg} \mathrm{P} \mathrm{kg}^{-1}$ & $4.72 \pm 0.29^{a}$ & $1.74 \pm 0.43^{b}$ & $0.10 \pm 0.03^{c}$ & $0.23 \pm 0.22^{c}$ \\
\hline Resin $\mathrm{P}(\text { Presin })^{\# \#}$ & $\mathrm{mg} \mathrm{P} \mathrm{kg}^{-1}$ & $69.3 \pm 3.7^{a}$ & $44.9 \pm 1.5^{b}$ & $26.1 \pm 0.6^{c}$ & $27.6 \pm 2.8^{c}$ \\
\hline Microbial P $\left(P_{m i c}\right)^{\# \# \#}$ & $\mathrm{mg} P \mathrm{~kg}^{-1}$ & $0.9 \pm 1.0^{d}$ & $13.8 \pm 2.2^{c}$ & $50.2 \pm 6.4^{b}$ & $93.7 \pm 15.3^{a}$ \\
\hline Inorganic $\mathrm{NaOH}$-EDTA P\#\# & $\mathrm{gP} \mathrm{kg}^{-1}$ & $2.23 \pm 0.09^{a}$ & $2.64 \pm 0.27^{a}$ & $1.37 \pm 0.05^{b}$ & $0.56 \pm 0.05^{c}$ \\
\hline Organic $\mathrm{NaOH}$-EDTA P & $\mathrm{gP} \mathrm{kg}^{-1}$ & $0.52 \pm 0.12^{\mathrm{c}}$ & $1.86 \pm 0.23^{b}$ & $2.64 \pm 0.23^{b}$ & $2.37 \pm 0.20^{\mathrm{ab}}$ \\
\hline $\mathrm{HCl} \mathrm{P}^{\prime \prime}$ & $\mathrm{g} \mathrm{P} \mathrm{kg}^{-1}$ & $1.95 \pm 0.08^{a}$ & $0.49 \pm 0.12^{c}$ & $1.76 \pm 0.05^{b}$ & $0.64 \pm 0.05^{c}$ \\
\hline Total P\#\#\# & $\mathrm{g} \mathrm{P} \mathrm{kg}^{-1}$ & $5.34 \pm 0.67^{a}$ & $4.92 \pm 0.35^{a}$ & $4.99 \pm 0.40^{a}$ & $3.52 \pm 0.12^{\mathrm{b}}$ \\
\hline $\mathrm{pH} \S$ & & 6.7 & 5.9 & 5.4 & 4.2 \\
\hline Potential acid phosphatase activity \#\#\# & $\mu \mathrm{mol} \mathrm{g}{ }^{-1} \mathrm{~h}^{-1}$ & $2.2 \pm 0.1^{\mathrm{d}}$ & $9.0 \pm 0.1^{c}$ & $16.0 \pm 0.5^{b}$ & $19.7 \pm 1.8^{\mathrm{a}}$ \\
\hline
\end{tabular}


Table 3: Oxygen isotopic signatures of soil water $\left(\delta^{18} \mathrm{O}-w_{\mathrm{s}}\right)$ and of phosphate of soil phosphorus pools $\left(\delta^{18} \mathrm{O}-\mathrm{P}\right.$ of resin, microbial, organic and inorganic $\mathrm{NaOH}$-EDTA and $\mathrm{HCl} \mathrm{P}$ pools) as well as calculated equilibrium values ( $E q-w_{s}$ and $\left.E q-w_{s+m}\right)$ before (day 0$)$ and 34 days after labelling with ${ }^{18} \mathrm{O}$ enriched water. Means and corrected sample standard deviations per site and time point.

\begin{tabular}{|c|c|c|c|c|c|}
\hline & \multirow[b]{2}{*}{$\begin{array}{l}\text { Time } \\
\text { [days] }\end{array}$} & \multicolumn{4}{|c|}{$\delta^{18} \mathrm{O}[\% 0]$} \\
\hline & & Site 1 & Site 2 & Site 3 & Site 4 \\
\hline \multirow[t]{2}{*}{ Soil water } & 0 & $-3.5^{\#}$ & $-2.2^{\#}$ & $-1.3^{\#}$ & $0.6^{\#}$ \\
\hline & 34 & $50.9^{\#}$ & $26.7^{\#}$ & $19.5^{\#}$ & $13.2^{\#}$ \\
\hline \multirow[t]{2}{*}{ Resin } & 0 & $22.8 \pm 0.2$ & $19.6 \pm 0.9$ & $15.5 \pm 3.6$ & $15.7^{\#}$ \\
\hline & 34 & $33.8 \pm 0.7$ & $26.5 \pm 2.1$ & $19.3 \pm 0.4$ & $20.9 \pm 1.5$ \\
\hline \multirow[t]{2}{*}{ Microbial } & 0 & $22.1 \pm 0.6^{\mathrm{H}}$ & $18.6 \pm 0.2^{\mathrm{H}}$ & $16.6 \pm 2.0$ & $11.5^{\#}$ \\
\hline & 34 & $32.7 \pm 2.6^{\mathrm{H}}$ & $25.5 \pm 1.4^{\mathrm{H}}$ & $20.9 \pm 0.4$ & $15.6 \pm 2.4$ \\
\hline \multirow[t]{2}{*}{ Organic $\mathrm{NaOH}$-EDTA } & 0 & NA & $18.6 \pm 0.5$ & NA & $21.4 \pm 0.5$ \\
\hline & 34 & NA & $20.3 \pm 0.1$ & NA & $21.5 \pm 0.6$ \\
\hline \multirow[t]{2}{*}{ Inorganic $\mathrm{NaOH}$-EDTA } & 0 & $26.4^{\#}$ & $23.7^{\#}$ & NA & NA \\
\hline & 34 & $27.6^{\#}$ & $23.9^{\#}$ & NA & NA \\
\hline \multirow[t]{2}{*}{$\mathrm{HCl}$} & 0 & $15.6^{\#}$ & $25.7 \pm 0.6$ & $24.6 \pm 1.0$ & $23.4 \pm 0.7$ \\
\hline & 34 & $14.7 \pm 0.3$ & $23.8 \pm 2.8$ & $23.1 \pm 1.1$ & $23.2 \pm 0.4$ \\
\hline \multirow{2}{*}{$\begin{array}{l}\text { Equilibrium Eq-Ws } \\
\text { (soil water) }\end{array}$} & 0 & $18.5^{\#}$ & $19.8^{\#}$ & $20.7^{\#}$ & $22.7^{\#}$ \\
\hline & 34 & $74.1^{\#}$ & $49.4^{\#}$ & $42.0^{\#}$ & $35.6^{\#}$ \\
\hline \multirow{2}{*}{$\begin{array}{l}\text { (soil water) } \\
\text { Equilibrium Eq-ws+m } \\
\text { (soil water and metabolic water)§ }\end{array}$} & 0 & $18.5^{\#}$ & $19.3^{\#}$ & $19.8^{\#}$ & $21.0^{\#}$ \\
\hline & 34 & $51.3^{\#}$ & $36.7^{\#}$ & $32.4^{\#}$ & $28.6^{\#}$ \\
\hline \multicolumn{6}{|c|}{$\# \mathrm{n}=1$ (standard deviation not determinable), otherwise $\mathrm{n}=2$} \\
\hline \multicolumn{6}{|c|}{$\begin{array}{l}\S \text { assumes } 41 \% \text { of metabolic water with given } \delta^{18} \mathrm{O} \text { of }-3.5 \% \text { in microorganisms } \\
\text { NA not analysed }\end{array}$} \\
\hline
\end{tabular}


Table 4: Incorporation of ${ }^{18} \mathrm{O}$ isotopes from soil water into phosphate (\%) of resin, microbial, organic and inorganic $\mathrm{NaOH}-\mathrm{EDTA}$, and $\mathrm{HCl}$ soil phosphorus pools during the incubation (34 days) per site. Means and corrected sample standard deviations per site and time point.

\begin{tabular}{lcccc}
\hline & Incorporation of ${ }^{18} \mathrm{O}$ in phosphate during incubation (34 days) (\%) \\
$\mathrm{P}$ pool & Site 1 & Site 2 & Site 3 & Site 4 \\
\hline Resin & $20 \pm 1$ & $24 \pm 8$ & $18 \pm 17$ & $41^{\#}$ \\
Microbial & $19 \pm 5^{\mathrm{H}}$ & $24 \pm 5^{\mathrm{H}}$ & $20 \pm 10$ & $33^{\#}$ \\
Organic NaOH-EDTA & $\mathrm{NA}$ & $6 \pm 2$ & $\mathrm{NA}$ & $1 \pm 6$ \\
Inorganic NaOH-EDTA & $2^{\#}$ & $1 \#$ & $\mathrm{NA}$ & $\mathrm{NA}$ \\
$\mathrm{HCl}$ & $-2^{\#}$ & $-7 \pm 10$ & $-7 \pm 7$ & $-1 \pm 6$ \\
\hline${ }^{\#} \mathrm{n}=1$ (standard deviation not determinable), otherwise $\mathrm{n}=2$ & & \\
${ }^{\mathrm{H}}$ calculated based on $\delta^{18} \mathrm{O}-P_{\text {hex }}$ values instead of $\delta^{18} \mathrm{O}-P_{\text {mic }}$ & & \\
\hline
\end{tabular}




\section{Figures}
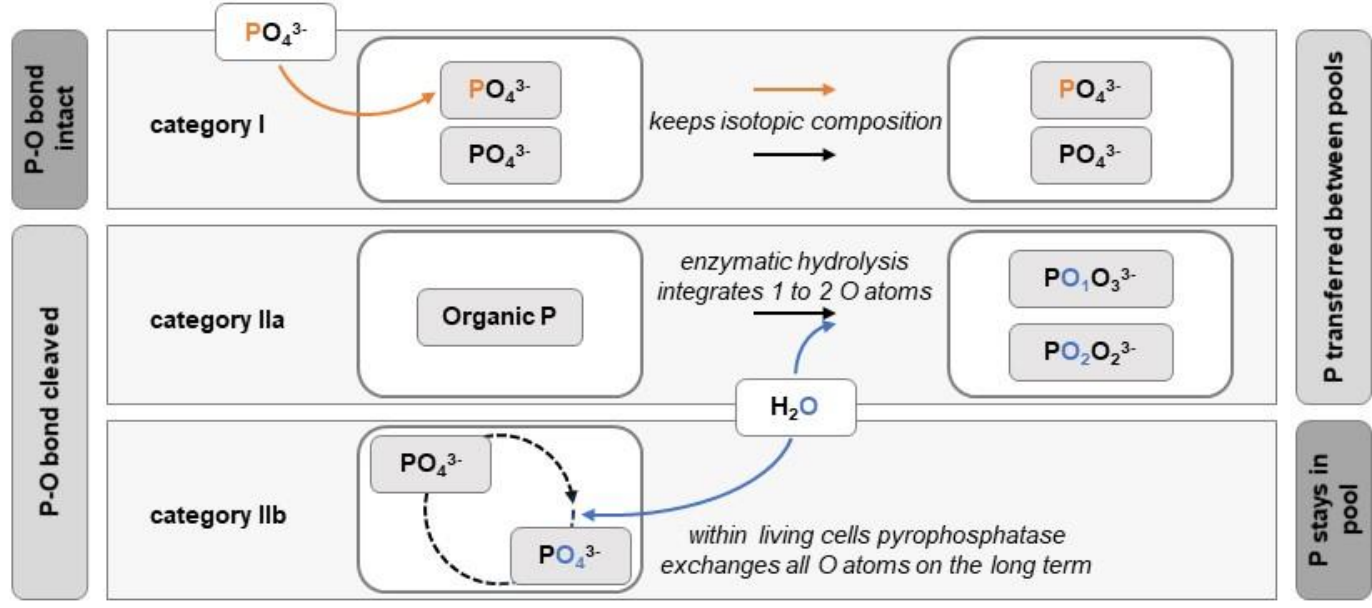

Figure 1: Conceptual visualisation of $\mathrm{P}$ cycling process categories and tracer $\left({ }^{32} \mathrm{P}\right.$ and $\left.{ }^{18} \mathrm{O}\right)$ movement within. 


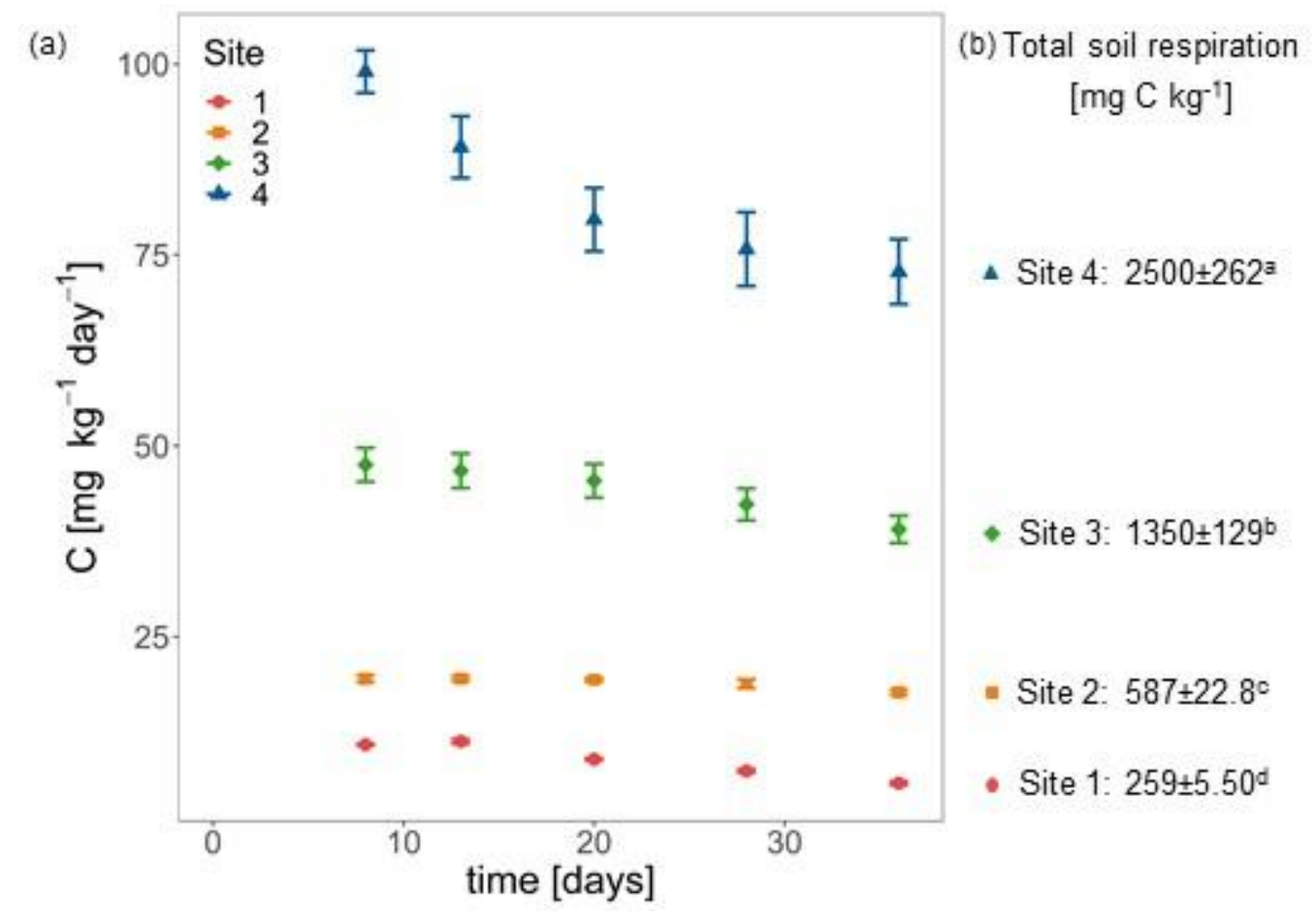

Figure 2: (a) daily ( $\mathrm{mg} \mathrm{C} \mathrm{kg}^{-1}$ dry soil day-1) and (b) total ( $\mathrm{mg} \mathrm{C} \mathrm{kg}^{-1}$ dry soil) soil respiration during the incubation period (36 days) measured 8, 13, 20, 28 and 36 days after incubation start. Means and corrected sample standard deviations per site and time point $(n=4)$, different letters in (b) denote significant differences $(\mathrm{P} \leq 0.05)$ among sites. 


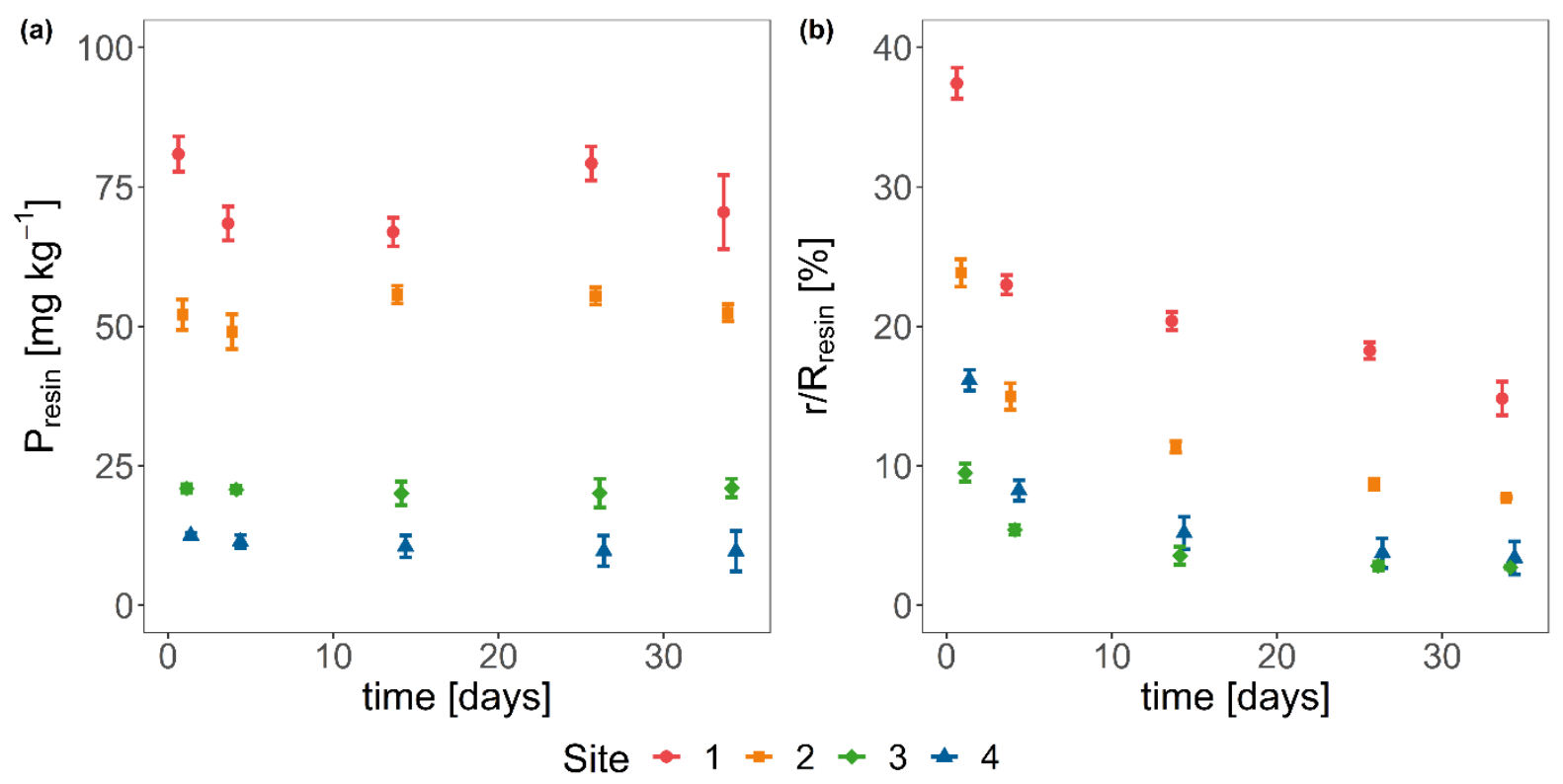

Figure 3: Resin (a) phosphorus concentration ( $\mathrm{mg} \mathrm{P} \mathrm{kg}^{-1}$ dry soil) and (b) radioactivity recovery $(r / R ; \%)$ at 1, 4, 14, 26 and 34 days after incubation start per site. Means and corrected sample standard deviations per site and time point $(n=4)$. 


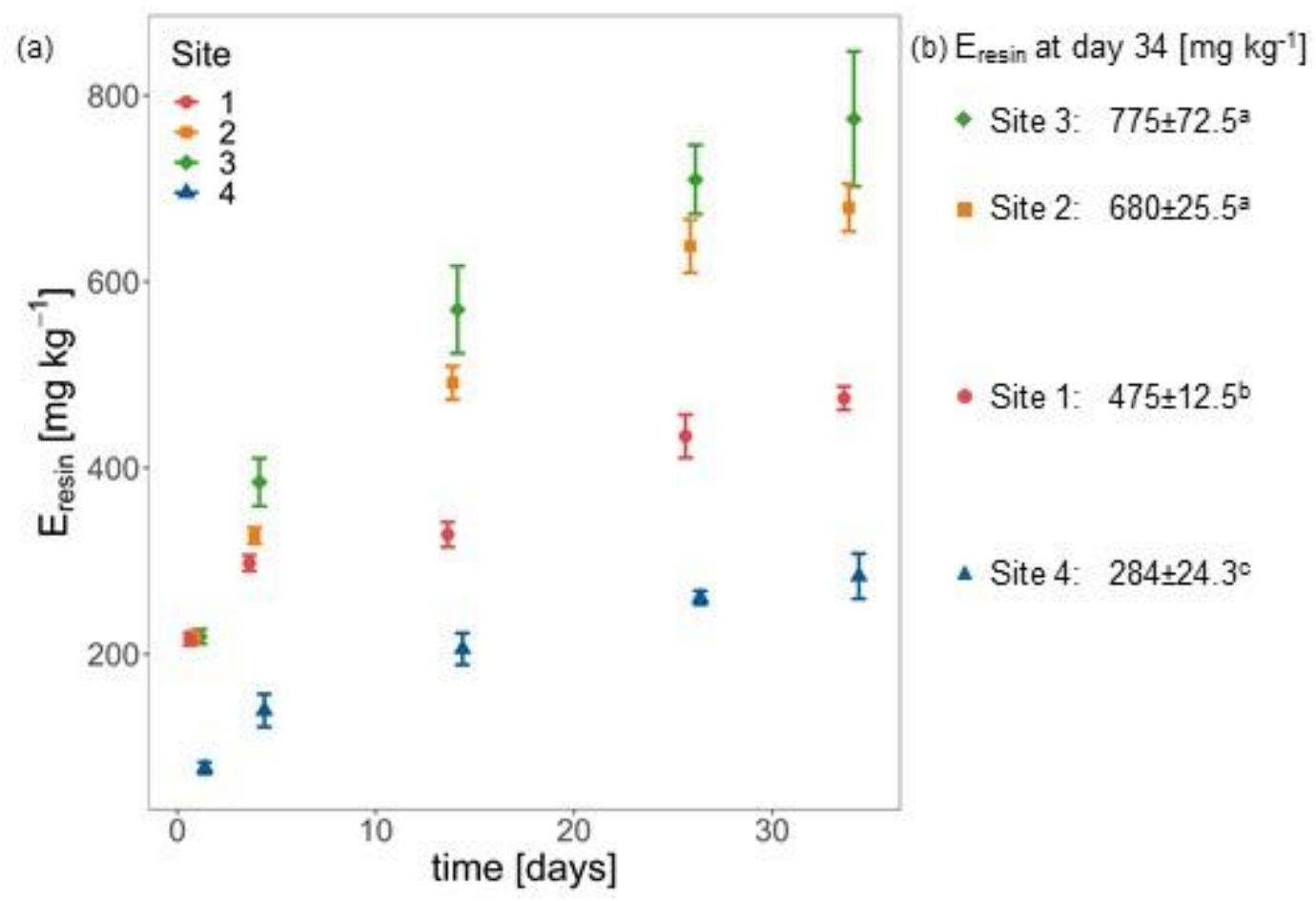

Figure 4: Amount of $\mathrm{P}$ isotopically exchangeable with $\mathrm{P}$ in resin pool (Eresin) in $\mathrm{mg} \mathrm{P} \mathrm{kg}^{-1} \mathrm{dry}$ soil at (a) 1, 4, 14, 26 and 34 days and at (b) 34 days after incubation start. Means and corrected sample standard deviations and time point $(n=4)$, different letters in (b) denote significant differences $(\mathrm{P} \leq 0.05)$ among sites. 


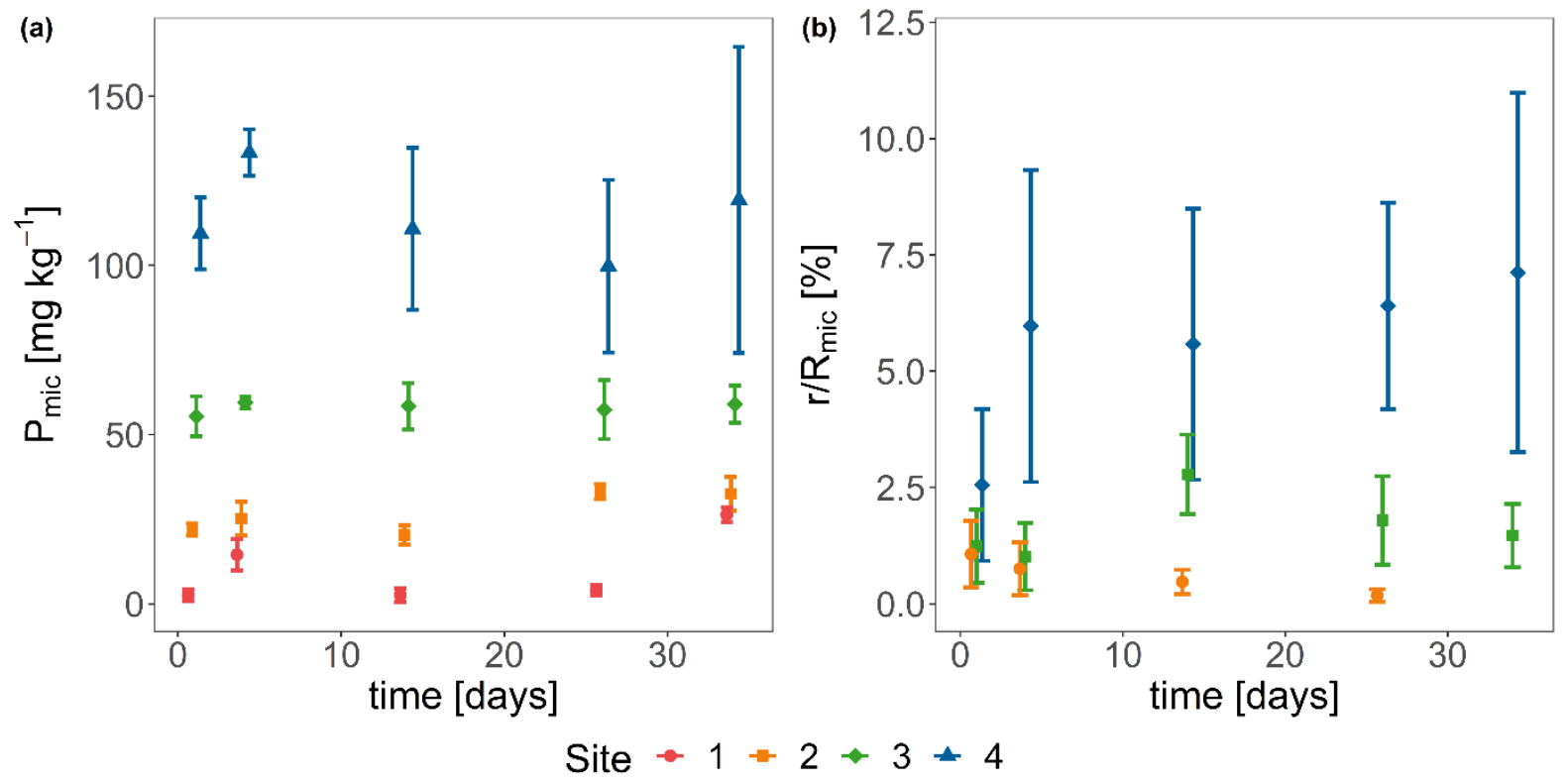

Figure 5: Microbial (a) phosphorus concentration (mg P kg-1 dry soil) and (b) radioactivity recovery $(\mathrm{r} / \mathrm{R} ; \%)$ at $1,4,14,26$ and 34 days after incubation start per site. Means and corrected sample standard deviations per site and time point $(\mathrm{n}=4) . r / R_{\text {mic }}$ of site 1 is not shown, 4 negative values obtained for $r / R_{\text {mic }}$ of site 2 at 34 days were removed from the dataset. 


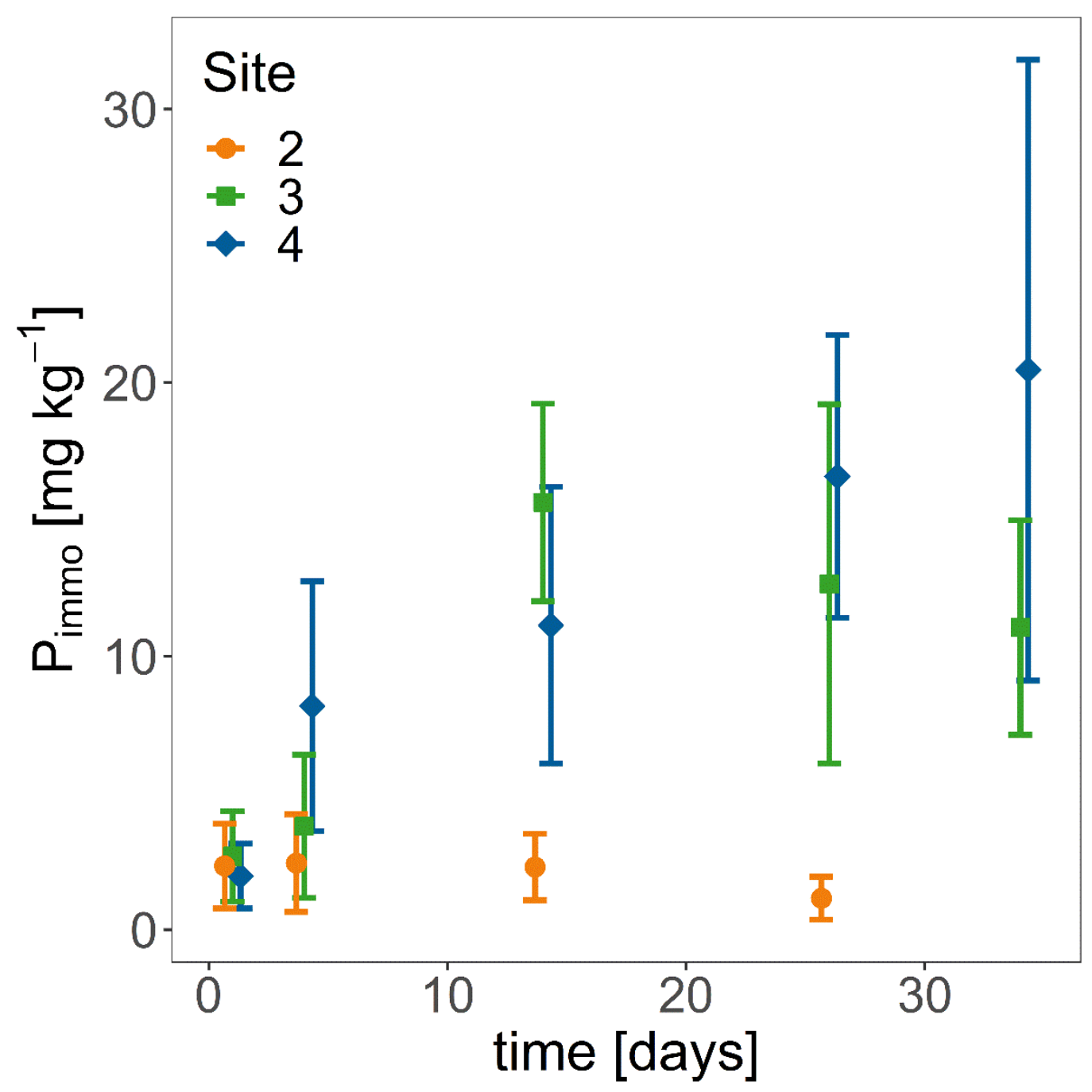

Figure 6: Fraction of microbial phosphorus derived from the resin phosphorus pool (gross $\mathrm{P}$ immobilisation, $P_{\text {immo }}$ in $\mathrm{mg} \mathrm{P} \mathrm{kg}^{-1}$ dry soil at 1, 4, 14, 26 and 34 days after incubation start. Means and corrected sample standard deviations per site and time point $(\mathrm{n}=4)$. $P_{\text {immo }}$ of site 1 is not shown, 4 negative values obtained for site 2 were removed from the dataset. 


\section{Supplementary}

\section{Sampling sites}

Table SM1: Sampling site description: position (latitude, longitude), elevation, mean annual precipitation (MAP), mean annual temperature (MAT), parent material, soil type, and dominant and additional plant species per site.

\begin{tabular}{|c|c|c|c|c|}
\hline & Site 1 & Site 2 & Site 3 & Site 4 \\
\hline Latitude $\left({ }^{\circ} \mathrm{N}\right)$ & 20.113 & 20.151 & 20.156 & 20.135 \\
\hline Longitude $\left({ }^{\circ} \mathrm{W}\right)$ & -155.880 & -155.821 & -155.797 & -155.748 \\
\hline Elevation (m a.s.I.) & 70 & 735 & 860 & 1059 \\
\hline $\mathrm{MAP}\left(\mathrm{mm} \mathrm{yr^{-1 } )}\right.$ & 275 & 1578 & 2163 & 3195 \\
\hline $\operatorname{MAT}\left({ }^{\circ} \mathrm{C}\right)$ & 23.6 & 19.1 & 17.8 & 16.2 \\
\hline Parent material & Hawi basalt & Hawi basalt & Hawi basalt & Hawi basalt \\
\hline Soil type & $\begin{array}{l}\text { medial-skeletal, } \\
\text { ferrihydritic, } \\
\text { isohyperthermic } \\
\text { Typic } \\
\text { Haplotorrands }\end{array}$ & $\begin{array}{l}\text { medial, amorphic, } \\
\text { isomesic Humic } \\
\text { Haplustands }\end{array}$ & $\begin{array}{l}\text { medial, amorphic, } \\
\text { isomesic Hydric } \\
\text { Fulvudands }\end{array}$ & $\begin{array}{l}\text { medial, amorpic, } \\
\text { isomesic Hydric } \\
\text { Fulvudands }\end{array}$ \\
\hline Dominantplant species & $\begin{array}{c}\text { buffel grass } \\
\text { Pennisetum ciliare }\end{array}$ & $\begin{array}{l}\text { kikuyu grass } \\
\text { Pennisetum } \\
\text { clandestinum }\end{array}$ & $\begin{array}{l}\text { kikuyu grass } \\
\text { Pennisetum } \\
\text { clandestinum }\end{array}$ & $\begin{array}{l}\text { kikuyu grass } \\
\text { Pennisetum } \\
\text { clandestinum }\end{array}$ \\
\hline Additional plant species & & $\begin{array}{l}\text { forage soybean } \\
\text { Neonotonia wightii } \\
\text { (Wight and Arn.) } \\
\text { J.A. Lackey }\end{array}$ & & $\begin{array}{l}\text { ohia Metrosideros } \\
\text { polymorpha } \\
\text { Gaudich. }\end{array}$ \\
\hline
\end{tabular}




\section{Specific activity in resin and microbial phosphorus pools}

Proportional specific activity in resin $\mathrm{P}$ ( $p S A_{\text {resin, }}$ Figure 5a) showed a clear decrease over time for all sites, indicating large $\mathrm{P}$ transfer from $P_{\text {resin }}$ to other $\mathrm{P}$ pools. The extremer sites showed larger $p S A_{\text {resin }}$ than the intermediate sites. Proportional specific activity in microbial $\mathrm{P}$ ( $p S A_{\text {mic }}$, Figure 5b) varied among time points for sites 2, 3 and 4 .

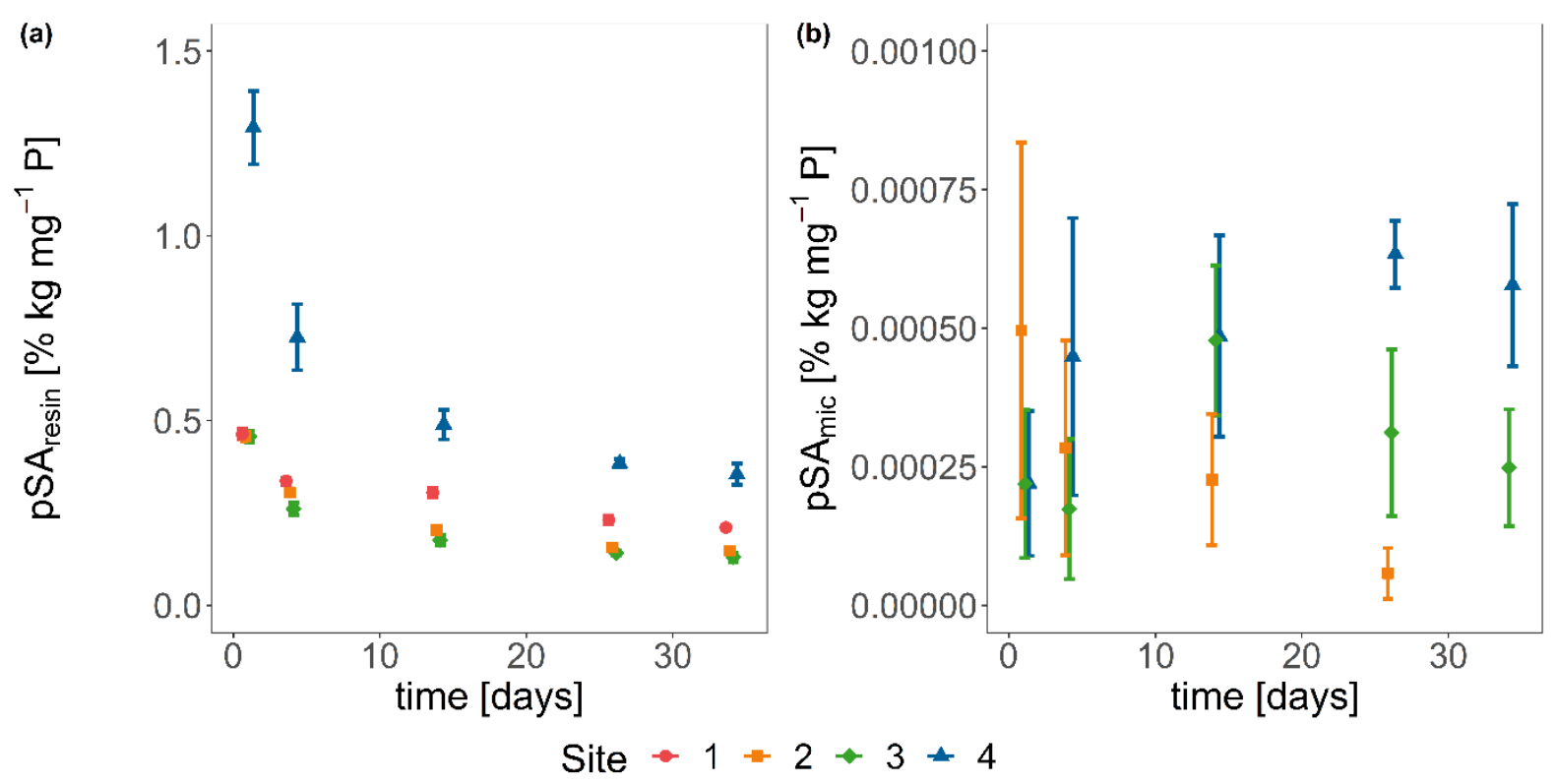

Figure SM1: Proportional specific activity ( $p S A, \% \mathrm{~kg}$ dry soil $\left.\mathrm{mg}^{-1} \mathrm{P}\right)$ of (a) resin and (b) microbial $P$ pools at $1,4,14,26$ and 34 days after incubation start per site $(n=4)$. Means and standard deviations per site and time point. $p S A_{\text {mic }}$ of site 1 is not shown, 4 negative values obtained for $p S A_{\text {mic }}$ of site 2 were removed from the dataset. 
Phosphorus pool concentration of Hedley extracts processed for the oxygen isotopic signatures

Table SM2: Phosphorus pool concentrations of the Hedley extracts processed for the oxygen isotopic signatures. Mean and standard deviations per time point and site, $n=2$.

\begin{tabular}{lccccc}
\hline \multicolumn{5}{c}{ P concentrations $\left[\mathrm{mg} \mathrm{P} \mathrm{kg}^{-1}\right]$} \\
\hline & $\begin{array}{c}\text { Time } \\
\text { [days] }\end{array}$ & 1 & 2 & 3 & 4 \\
\hline Resin & 0 & $62.3 \pm 0.8$ & $37.5 \pm 0.7$ & $10.6 \pm 0.5$ & $8.3 \pm 0.8$ \\
& 34 & $44.3 \pm 3.0$ & $28.3 \pm 1.8$ & $6.5 \pm 0.4$ & $3.5 \pm 2.6$ \\
\hline Microbial & 0 & $1.9 \pm 2.4$ & $17.6 \pm 0.7$ & $27.1 \pm 3.7$ & $87.7 \pm 1.5$ \\
& 34 & $6.3 \pm 2.6$ & $11.4 \pm 4.2$ & $21.1 \pm 3.1$ & $46.8 \pm 28.4$ \\
\hline Organic & 0 & $279.9 \pm 421.2$ & $1745.5 \pm 63.1$ & $1427.6 \pm 286.9$ & $2161.2 \pm 82.2$ \\
NaOH-EDTA & 34 & $675.8 \pm 453.2$ & $765.7 \pm 228.7$ & $2066.6 \pm 862.4$ & $1627.4 \pm 261.6$ \\
\hline Inorganic & 0 & $2225.8 \pm 142.1$ & $2028.5 \pm 44.4$ & $1136.8 \pm 74.4$ & $548.8 \pm 60.7$ \\
NaOH-EDTA & 34 & $1979.6 \pm 63.2$ & $1891.6 \pm 114.8$ & $1146.6 \pm 8.4$ & $495.9 \pm 14.8$ \\
\hline HCl & 0 & $865.6 \pm 12.7$ & $202.2 \pm 0.1$ & $697.5 \pm 27.3$ & $305.8 \pm 4.2$ \\
& 34 & $958.8 \pm 170.7$ & $210.0 \pm 57.4$ & $837.3 \pm 16.0$ & $284.2 \pm 48.7$ \\
\hline
\end{tabular}

